\title{
Holocene paleoenvironments in southeastern Minnesota - chasing the prairie-forest ecotone
}

\author{
R.G. Baker*, E.A. Bettis III, R.F. Denniston ${ }^{1}$, L.A. Gonzalez, \\ L.E. Strickland ${ }^{2}$, J.R. Krieg \\ Department of Geoscience, University of Iowa, Iowa City, IA 52242-1379, USA
}

Accepted 16 August 2001

\begin{abstract}
This paper uses a multi-proxy approach involving pollen, plant macrofossils, speleothem isotopes, and alluvial history of streams to reconstruct the history of prairie expansion and contraction along the prairie-forest border of southeastern Minnesota, USA. Early Holocene forests were replaced by prairie along this border, but eastward expansion of prairie stalled for $2000 \mathrm{yr}$ when the prairie-forest ecotone stabilized. Prairie invaded the area from the west $8000-9000$ yr B.P., but mesic forest remained less than $100 \mathrm{~km}$ to the east until about $6000 \mathrm{yr}$ B.P. Changes in $\delta^{13} \mathrm{C}$ values in speleothem calcite, that reflect the rise of $\mathrm{C}_{4}$ grasses, correlate well with the presence of $\mathrm{C}_{4}$ grass species identified in the plant macrofossil record. Periods of large floods correlate with speleothem evidence of dry summers, increased cool-season precipitation (both resulting in less plant cover to absorb moisture), and change to prairie vegetation. (C) 2002 Elsevier Science B.V. All rights reserved.
\end{abstract}

Keywords: grasslands; paleoenvironment; pollen; plant macrofossils; speleothems; alluvial history

\section{Introduction}

Many researchers working on the paleoenvironmental history of grasslands have lamented that we could only identify main grass groupings $\left(\mathrm{C}_{3}\right.$ vs $\mathrm{C}_{4}$, or various tribes), because no fossil evidence (including pollen, phytoliths, and carbon isotopes) permitted the identification of grass and forb species. If this level of identification

\footnotetext{
1 Present address: Geology Department, Cornell College, Mt. Vernon, IA 52314, USA.

2 Present address: Earth Surfaces Processes, U.S. Geological Survey, Box 25046 MS 980, Denver Federal Center, Lakewood, CO 80225, USA.

* Corresponding author.
}

were possible, we could determine exactly what species assemblages were present in past communities. This paper presents such evidence as part of an integrated study of Holocene environmental change involving the prominent prairie-forest ecotone in southeastern Minnesota and northeastern Iowa, USA. The paper uses pollen and especially plant macrofossils from small-stream deposits to reconstruct the chronology of vegetational change along this ecotone, and these changes are used to infer climatic conditions. The history of fluvial activity of the stream is also presented, and the importance of both climate and vegetation are discussed as potential forcing functions of changes in the pattern of erosion, stability, and deposition along the stream. These environmental changes 
are then correlated with high-resolution carbonand oxygen-isotopic records from calcite in nearby cave speleothems.

The history of Holocene prairie expansion and contraction in the Midwest has been discussed for over $75 \mathrm{yr}$ beginning with Gleason (1922). For the last $35 \mathrm{yr}$ paleoecologists have accumulated abundant and reliable pollen data (Cushing, 1965; Wright 1968; Grimm, 1984). Yet there are still major questions. It is well established from many sites that drier conditions began in the early Holocene from the western Great Plains eastward to northwestern and central Minnesota (Webb et al., 1983; Barnosky et al., 1987). In northwestern Minnesota, this history has been worked out in exquisite detail (McAndrews, 1966; Bradbury and Dean, 1993), indicating especially arid conditions from about 8000 to $4000 \mathrm{yr}$ B.P. (uncalibrated ${ }^{14} \mathrm{C}$ yr before present). The scarcity of lakes and wetlands south of the Late Wisconsin glacial border has led us to investigate stream sediments and cave speleothems as sources of paleoenvironmental reconstruction (Baker et al., 1996, 1998; Denniston et al., 1999a,b).

Recent work has indicated that maximum aridity in southern Wisconsin and eastern Iowa was later, from about 5500 to ca. 3500 yr B.P., and climate remained moist until mid-Holocene time (Baker et al., 1992, 1996; Chumbley et al., 1990). A sharp early to mid-Holocene climatic boundary has been documented between these regions (Baker et al., 1990, 1992), but its position is still not well established. Furthermore, the boundary was proposed largely on the basis of evidence from plant remains in stream deposits; this technique appears to be powerful, but it needs further testing.

This paper tests (1) the hypothesis that a sharp mid-Holocene climatic and vegetational boundary extended northward from Iowa into southeastern Minnesota, (2) the reliability of using fossils in stream cutbanks by comparing these new sites with the Roberts Creek sites in northeastern Iowa and with high-resolution isotopic chronologies and (3) the consistency of the relationship between climate, vegetation, and stream activity at new sites.

To accomplish these goals, we (1) report on the detailed paleoecology derived from plant macro- fossils and pollen at sites from two nearly adjacent valleys, Money Creek and Pine Creek (MO on Fig. 1), in southeastern Minnesota, (2) describe the alluvial stratigraphy of outcrops that illustrates the pattern of Holocene alluvial cut-andfill on many Midwestern floodplains, and relate that history to the climatic and vegetational changes, (3) compare these data with carbon isotopic studies of speleothems from caves in southeastern Minnesota and northeastern Iowa, and (4) use these data to define the position of the mid-Holocene climatic boundary across the central Midwest.

We sought to test the hypothesis that a midHolocene climatic boundary extended northward from Iowa into Minnesota by finding a site between Kirchner Marsh in southeast central Minnesota (Fig. 1), where drying occurred in the early Holocene (Watts and Winter, 1966), and northeastern Iowa, where dry conditions did not develop until mid-Holocene time (Baker et al., 1996).

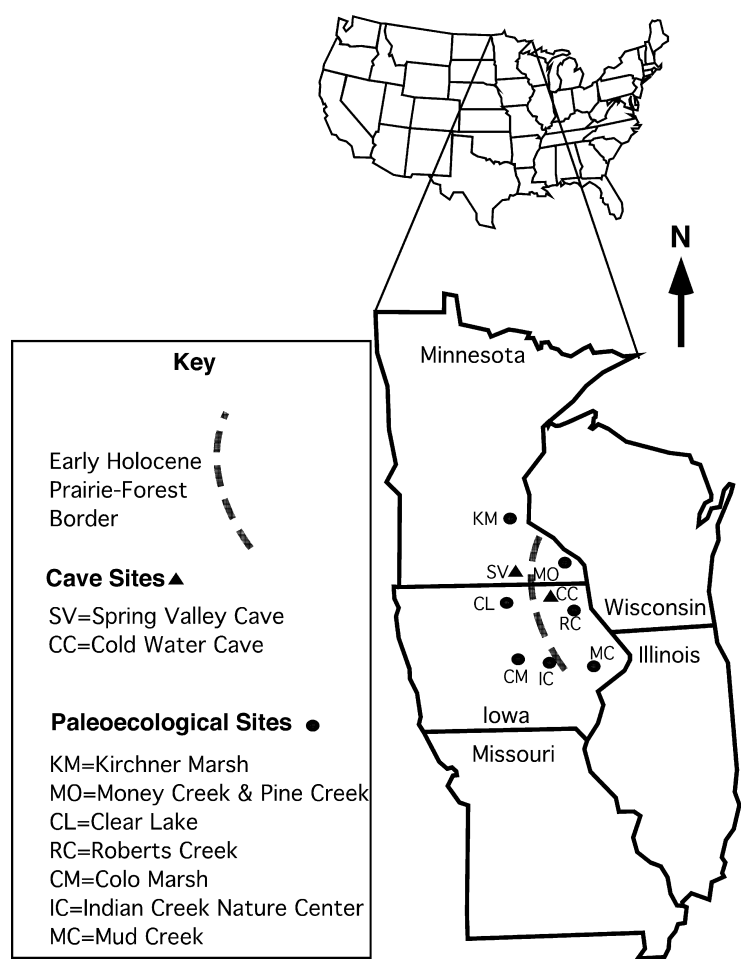

Fig. 1. Map of central Midwest showing locations of cave and paleoecological sites used to constrain mid-Holocene prairie-forest boundary. Money Creek and Pine Creek are within the dot for locality MO. 
Organic-rich sediments were discovered in alluvium in two nearly adjacent stream valleys in southeastern Minnesota in the area of the proposed

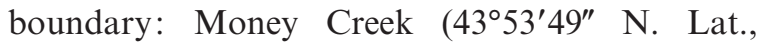

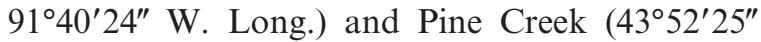
N. Lat., 91 $28^{\prime} 20^{\prime \prime}$ W. Long.), Winona Co., MN, USA (Fig. 1). We used the record of plant remains and cut-and-fill relationships exposed in the banks of these small streams, as described by Baker et al. (1996) to reconstruct the vegetational and alluvial history. Each cutbank locality represents a rich fossil assemblage providing a snapshot of $<100-200 \mathrm{yr}$ of deposition. These sites differ from those at Roberts Creek in northeastern Iowa (Chumbley et al., 1990; Baker et al., 1996), however, in that they are in a landscape of valleys deeply incised into bedrock, with $100 \mathrm{~m}$ or more of relief. This landscape houses abundant microhabitats related to slope aspect, bedrock, local groundwater flow, and other local features, that have been important influences on vegetation during the Holocene.

The carbon and oxygen isotopic composition of speleothem calcite has been used for paleoclimate reconstruction (Dorale et al., 1992). The $\delta^{18} \mathrm{O}$ of speleothem calcite has been interpreted as reflecting the isotopic composition of precipitation and mean annual temperature (Hendy and Wilson, 1968; Dorale et al., 1992). However, these relationships can be complicated by evaporative enrichment of ${ }^{18} \mathrm{O}$ in meteoric waters prior to their infiltration into the subsurface (Denniston et al., 1999a). Speleothem $\delta^{13} \mathrm{C}$ may also record changes in vegetation. The carbon in speleothem calcite is derived from dissolution of carbonate bedrock and decay of soil organic matter (atmospheric $\mathrm{CO}_{2}$ is negligible). Because $\delta^{13} \mathrm{C}$ values of $\mathrm{C}_{4}$ plants $(-19 \%$ o to $-9 \%$ ) are higher than those of $\mathrm{C}_{3}$ vegetation $(-32 \%$ o to $-20 \%$ ), increases in $\mathrm{C}_{4} / \mathrm{C}_{3}$ ratios also increase $\delta^{13} \mathrm{C}$ values of soil organic matter (Boutton, 1991). This carbon isotopic signal is transported vertically downward with infiltrating fluids and is eventually recorded by higher $\delta^{13} \mathrm{C}$ of speleothem calcite. Because carbon is added to solutions after it has penetrated below the land surface, it does not suffer from pre-infiltration effects and is therefore a reliable tool for reconstructing paleovegetation.

\section{Study area}

Money and Pine Creeks are tributaries of the Root and Mississippi Rivers respectively, that flow southeastward through the so-called 'Driftless Area' of southeastern Minnesota, an extension of Iowa's Paleozoic Plateau landform region (Fig. 1; Prior, 1991). The region's landscape reflects a strong influence of underlying Paleozoic marine carbonate and sandstone bedrock and was formerly included in the 'Driftless Area' of the Upper Mississippi Valley, a designation now known to be incorrect (Knox and Attig, 1988; Hobbs, 1995). Valleys are narrow and deeply entrenched with steep, rocky valley walls. Uplands are moderately to steeply sloping and a thin (1$10 \mathrm{~m}$ thick) mantle of Pleistocene deposits covers the bedrock surface (Hobbs, 1995). The ground water table of the Cambrian sandstone aquifer is intersected by streams in the study area, and ground water discharges to the streams from the bedrock units, fostering continual saturation and preservation of organic plant remains in the basal parts of these valleys' alluvial fill.

The area has a continental climate, with a mean annual temperature of $46^{\circ} \mathrm{F}$. $\left(7.7^{\circ} \mathrm{C}\right.$.) and a mean annual precipitation of 33 inch $(108 \mathrm{~cm})$ at nearby Winona, MN. Precipitation is highest in the summer months. The pre-settlement vegetation in this area consisted of deciduous forest. Common forest trees included Quercus macrocarpa (bur oak), Quercus alba (white oak), Quercus rubra (red oak), Acer saccharum (sugar maple), Tilia americana (basswood), Fraxinus pennsylvanica (green ash), Ulmus americana (American elm), Ulmus rubra (red elm), Carya cordiformis (bitternut hickory), Juglans cinerea (butternut), Populus tremuloides (aspen) and Ostrya virginiana (hophornbeam) (Grimm, 1984; Strickland, 1998). The prairie-forest ecotone was an irregular transition zone only a few $\mathrm{km}$ to the west. Beyond that the prairie was dominated by tall $\mathrm{C}_{4}$ grasses including Andropogon gerardii (big bluestem), Schizachyrium scoparium (little bluestem), and Sorghastrum nutans (Indian grass), along with members of the sunflower (Asteraceae) family, including Helianthus spp. (sunflower) and Heliopsis helianthoides (ox-eye), and legume (Fabaceae) 
family, including Amorpha canescens (leadplant) and Desmodium spp. (tick-trefoil). These taxa listed are ones that also occur in our fossil records.

Money and Pine creeks are 4th-order valleys with drainage areas of approximately $42 \mathrm{~km}^{2}$ and $60 \mathrm{~km}^{2}$ respectively at the study areas. The valley floors of the creeks range in width from 0.2 to $0.4 \mathrm{~km}$, and both creeks meander within their valleys, though several segments of each have been artificially straightened. The creeks flow through channels $2-4 \mathrm{~m}$ in width and 2-3 m deep. Both streams have pool and riffle morphology, with low-gradient, mud bottom, quiet water pools separated by short, steep-gradient, cobblebottom, swift-water riffles. During low-flow conditions in most summers water depth ranges from 0.5 to $1.5 \mathrm{~m}$ in pools to $0.2-0.1 \mathrm{~m}$ in riffles. High water conditions are usually associated with spring snow melt and thunderstorms, while lowflow conditions, when most of the stream's flow is supplied by ground water discharge, usually occur during the summer and early fall.

\section{Methods}

Samples of organic-rich sediments were collected in cutbanks along the upper reaches of Money Creek and Pine Creek by shovel, stored in sealable plastic bags, and brought to the lab. Sediments and soils were described along Money Creek using standard terminology and procedures (Soil Survey Staff, 1993). Pollen samples from the same sediment used for macrofossils were processed using $\mathrm{KOH}, \mathrm{HCL}, \mathrm{HF}$, and acetolysis solution as described in Faegri et al. (1989) with further screening after treatment with $0.1 \mathrm{~N}$ sodium pyrophosphate followed by dilute $(0.2 \%)$ bleach $(\mathrm{NaOCl})$. Sediment samples of $200 \mathrm{ml}$ were washed through 0.5 - and $0.1-\mathrm{mm}$ sieves for plant macrofossils, picked by hand, and stored in glycerin with crystals of phenol. Because of the large volume of fine-grained sediment, it was impractical to pick through all the fine residue; a minimum of three dishes $(10 \mathrm{~cm}$ diameter $)$ were picked from each level. More material was picked if new taxa continued to be found. As a result, macrofossils between 0.5 and $1 \mathrm{~mm}$, marked with an asterisk on the diagrams, are minimum values. Macrofossils are mostly seeds and fruits, unless otherwise labeled. All grass macrofossils identified were florets. Pollen and plant macrofossils were identified using reference collections at the Geoscience Department, University of Iowa. Macrofossil specimens and pollen slides are preserved in the Geological Repository there, and complete macrofossil data are on file at the North American Plant Macrofossil Database, at the National Geophysical Data Center, Boulder, CO, USA. Diagrams were plotted using Tiliagraph 2.0.b.5. Radiocarbon dates (Table 1) were obtained from wood collected from each cutbank. Unless otherwise specified, all radiocarbon dates are in uncalibrated ${ }^{14} \mathrm{C}$ yr B.P. (before present).

Stalagmites were sawed in half vertically, polished, and sampled for carbon and oxygen isotopes at intervals ranging from 1 to $3 \mathrm{~mm}$ using a modified dental drill with a $500-\mu$ m-diameter bit. Carbon and oxygen isotopic analyses were performed at the University of Michigan Stable Isotope Laboratory using a MAT-251 gas-source mass spectrometer. Samples were converted to $\mathrm{CO}_{2}$ by reacting them with phosphoric acid at $72^{\circ} \mathrm{C}$. All values are reported in \%o with oxygen relative to SMOW and carbon relative to PDB; analytical precision is greater than $0.1 \%$ for both carbon and oxygen.

Powders were similarly extracted for ${ }^{238} \mathrm{U}$ ${ }^{234} \mathrm{U}-{ }^{230} \mathrm{Th}$ dating by thermal ionization mass spectrometry (TIMS) at the University of Minnesota for the Spring Valley stalagmite and at Los Alamos National Laboratories for the Cold Water Cave stalagmite (Dorale et al., 1992). Analytical procedures are modifications of those discussed in Chen et al. (1986) and Edwards et al. (1987; 1993).

\section{Results}

\subsection{Alluvial history}

The valley floors of both Money and Pine creeks consist of four alluvial surfaces designated T0-T3. T3 is the highest surface and is elevated 
about $3 \mathrm{~m}$ above creek level at low flow. T3 is level and merges in a smooth, concave upward profile with small, loess-free colluvial slopes along the valley margins. This terrace is underlain by loamy alluvium that grades downward into silty and gravelly alluvium. T2 is separated from T3 by a long gentle scarp and is approximately $0.2-0.5 \mathrm{~m}$ lower in elevation than T3. T2 is underlain by loamy grading downward to gravelly alluvium. T1, separated from T2 by a sort, steep, $0.3-0.8 \mathrm{~m}$ high scarp, is marked with shallow, filled abandoned meander scars and subtle undulations. T1 roughly parallels the modern (unstraightened) channel and is underlain by loamy alluvium that grades downward to gravelly alluvium. T0, the lowest surface in the valley, is the modern channel belt, separated from older surfaces by a short, steep one to two meter high scarp and characterized by abandoned meanders that contain water, small natural levees, and partially masked to active point bars and chutes. T0 is flooded annually.

The valley floor surfaces are underlain by $3-4 \mathrm{~m}$ of DeForest Formation alluvium (Bettis et al., 1992; Baker et al., 1996; Bettis and Autin,
1997). The alluvial fill consists of three lithologically distinct units, the Gunder, Roberts Creek, and Camp Creek members of the formation (Fig. 2). Table 2 summarizes the lithologic (texture, color, bedding structures, pedogenic alterations) properties of DeForest Formation units in Money and Pine Creek valleys.

Gunder Member deposits, averaging 3-4 $\mathrm{m}$ in thickness, underlie the two highest valley surfaces (T3 and T2). Gunder Member deposits beneath T3 are siltier and thicker than those beneath T2, and point bar gravels beneath $\mathrm{T} 2$ are thicker than those beneath T3. Basal radiocarbon ages on wood from the Gunder Member in Money and Pine creeks range from 11450 to $8120 \mathrm{yr}$ B.P. beneath T3, and 6060 to 5090 yr B.P. beneath T2 (Table 1). The Roberts Creek Member averages $2-3 \mathrm{~m}$ in thickness and underlies T1. Roberts Creek Member point bar gravels are thinner than those of the Gunder Member beneath T2, and similar in thickness to those of the Gunder Member beneath T3. Radiocarbon ages from the Roberts Creek Member range from 3850 to 1780 B.P. in these valleys (Table 1). Camp Creek Member

Table 1

Radiocarbon ages and estimated post-settlement age from Money Creek and Pine Creek

\begin{tabular}{llllr}
\hline Site & ${ }^{14}$ C ages & Unit & Lab no. & Cal. age \\
\hline Money Cr., Site 6 & post-settlement & CC & & 100 \\
Money Cr., Site 9 & $1780 \pm 70$ & RC & ISGS-3622 & 1700 \\
Money Cr., Site 9 & $1820 \pm 50$ & RC & NSRL-3510 (CAMS-36636) & 1720 \\
Pine Cr., Site 2A & $3060 \pm 70$ & RC & ISGS-3432 & 3260 \\
Pine Cr., Site IVA & $3110 \pm 70$ & RC & Beta-84021 & 3350 \\
Money Cr., Site 9, N. end & $3320 \pm 70$ & RC & ISGS-3756 & 3510 \\
Money Cr., Site 1 & $3580 \pm 70$ & RC & ISGS-3220 & 3860 \\
Money Cr., Site 4 & $3830 \pm 70$ & RC & ISGS-3247 & 4230 \\
Money Cr., Site 15 & $3850 \pm 80$ & RC & ISGS-3625 & 4240 \\
Money Cr., Site 7 & $4390 \pm 140$ & RC & ISGS-3438 & 4930 \\
Money Cr., Site 10 & $5090 \pm 70$ & LG & ISGS-3245 & 5790 \\
Money Cr., Site 5 & $5340 \pm 70$ & LG & ISGS-3624 & 6140 \\
Money Cr., Site 13 & $5410 \pm 70$ & LG & ISGS-3623 & 6250 \\
Pine Cr., Site I & $5540 \pm 60$ & LG & CAMS-33983 & 6310 \\
Pine Cr., Site 3 & $5920 \pm 60$ & LG & ISGS-3621 & 6740 \\
Money Cr., Site 14 & $5980 \pm 110$ & LG & ISGS-3217 & 6830 \\
Money Cr., Site 3 & EG & ISGS-3248 & 6890 \\
Money Cr., Site 8 & $6060 \pm 70$ & EG & ISGS-3763 & 8990 \\
Money Cr., Site 9 & $8120 \pm 90$ & EG & ISGS-3755 & 9250 \\
Money Cr., Site 9, S end & $8270 \pm 100$ & EG & ISGS-3222 & ISGS-3221 \\
Money Cr., Site 2, top & $8340 \pm 210$ & EG & I & \\
Money Cr., Site 2, bottom & $11290 \pm 100$ & CE & 13200
\end{tabular}

$\mathrm{EG}=$ early Gunder, $\mathrm{LG}=$ late Gunder, $\mathrm{RC}=$ Roberts Creek, CC = Camp Creek 


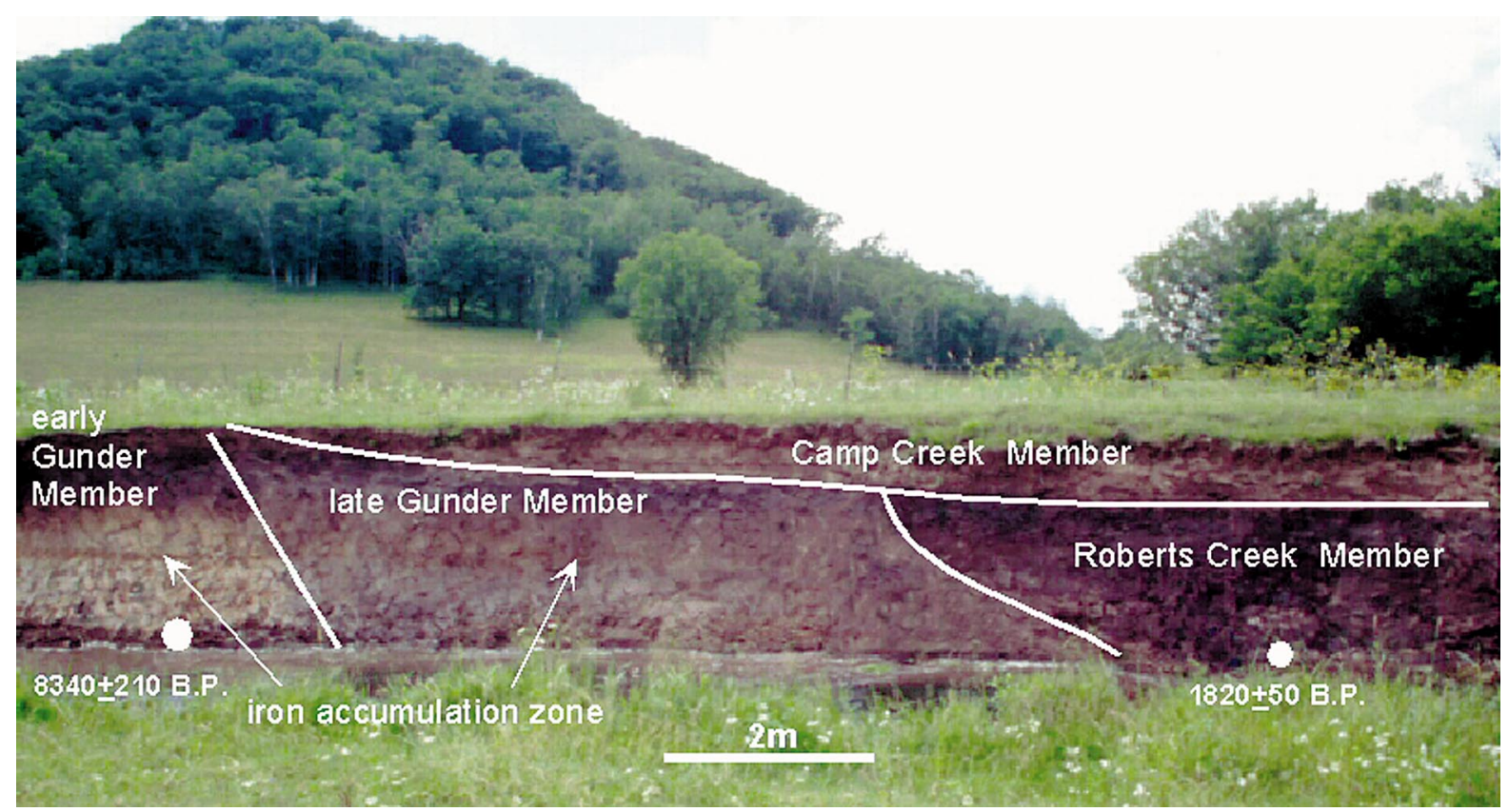

Fig. 2. Photograph of section at Site 9, Money Creek, showing alluvial units and radiocarbon ages.

deposits underlie T0 (the modern channel belt) and lap up onto T1 and T2. Elsewhere in the Upper Midwest the bulk of the Camp Creek Member is Historic in age (Bettis et al., 1992; Beach, 1994; Baker et al, 1996; Bettis and Autin, 1997). Although no datable material or artifacts were recovered from the Camp Creek Member during this study, its lithology, distribution relative to other DeForest Formation units, and general lack of pedogenic alteration suggest it is of Historic age.

The overall sedimentology of the Gunder and

Table 2

Lithologic and chronologic characteristics of DeForest Formation alluvium in Money and Pine creeks.

\begin{abstract}
Camp Creek Member
Very dark grayish brown to yellowish brown (10YR3/2-5/4) silt loam to loam with thin sandy loam beds in abandoned channel areas; sand and gravel in the active channel; non-effervescent; horizontally stratified where greater than $0.25 \mathrm{~m}$ in thickness; surface soils (where present) are Entisols (A-C profiles); unit often buries pre-settlement surface soil; thickest in and adjacent to channel belt (T0), and at the base of steep slopes. Not directly dated in this study; elsewhere in the Upper Midwest, USA ca. 150 B.P. to present.
\end{abstract}

\title{
Roberts Creek Member
}

Very dark gray to grayish brown (2.5Y3/0-10YR3/1-3/2) silty clay loam, and loam grading downward to sand and gravel; non-effervescent; thick sections are horizontally stratified at depth; detrital organic matter in lower part; relatively thick Mollisol (A-C or A-Bw-C profile) developed in upper part; B horizon (if present) is dark colored; strong brown and yellowish red (7.5YR5/8, and 5YR5/8) mottles may occur throughout unit; found beneath T1, usually parallelling modern channel belt, ca. $4390-1000$ B.P.

\section{Gunder Member}

Brown to yellowish brown to grayish brown (10YR4/3-5/4 to $2.5 \mathrm{Y} 5 / 2)$ silt loam (early Gunder) or brown to dark grayish brown (10YR4/3-4/2) loam (late Gunder) grading to sand and gravel at depth; non-effervescent; lower part may be horizontally stratified; detrital organic matter often present in lower, unoxidized part of unit; thick Mollisol or Alfisol (A-Bt-C, or A-E-Bt-C profile in early Gunder or A-Bw-C in late Gunder) developed in upper part; B horizon is brown to yellowish brown; C horizon usually contains strong brown (7.5YR5/8), yellowish red (5YR5/8), or dark brown (10YR3/3) mottles; comprises alluvial fill beneath T3 (early Gunder) and T2 (late Gunder). Early Gunder 11,450 to 8120 B.P.; late Gunder 6060-5090 B.P. 
Roberts Creek Members is similar. Both units are characterized by a $0.8-1.3-\mathrm{m}$-thick basal cobble gravel (lag) composed of clasts of local carbonate and sandstone that overlies bedrock. This channel bottom lag gravel maintains a uniform cross-valley elevation beneath all valley surfaces, indicating that channel bottom cutting and filling have been insignificant during the last ca. $11500 \mathrm{yr}$. The channel bottom lag is overlain by about $0.3-0.7$ $\mathrm{m}$ of sandy and/or pebbly sand in-channel deposits that grade upward to fine-grained alluvium, or by $0.6-1.6-m$-thick sandy gravel point bar deposits overlain by fine-grained alluvium. Thin horizontal stratification is often present in the transition zone from the sandy to the fine-grained deposits.

In nearby southwestern Wisconsin Knox (1985, 1993) also found insignificant Holocene channel bottom cutting and filling, and used the modern channel bed level as a reference against which past flood depths could be compared. He found that point bar deposits dating between 6000 and 4500 yr B.P. were significantly thicker than those preceding and post-dating that period, and concluded that the larger bars were formed during a period of relatively large floods (Knox, 1985). In a later paper, he computed paleoflood depths using cobbles or boulders found in overbank flood deposits (flood ramps) and found, in contrast to his 1983 study, that the period between 3300 and 5000 yr B.P. was characterized by relatively small floods (Knox, 1993). Point bar gravels associated with Gunder Member alluvium beneath T2 (ca. 6000-5000 yr B.P.; 6900-5800 yr ago) are thicker than older or younger point bar deposits in both Money and Pine creeks. In addition, more flood ramp deposits, and larger average clast size in the flood ramp deposits, are also associated with the Gunder Member alluvium beneath T2. We conclude that the larger point bars and more frequent and larger-clast flood ramps associated with alluvium dating from ca. 6000-5000 yr B.P. indicate a period of larger floods. Larger floods would also promote increased channel migration, channel belt widening, and accelerated removal of older alluvium. This would create many floodplain environments favorable for pioneer species. Point bar and flood ramp deposits dating to the periods
11450-8200 and after 4000 yr B.P. suggest smaller, less competent floods during these periods. The Historic period witnessed a return to larger floods, which deposited alluvium over all but the highest valley surfaces.

Plant macrofossils are preserved primarily in the sandy in-channel deposits and in the overlying stratified transitional deposits. The thickest plant macrofossil-bearing deposits (approximately 0.5 $\mathrm{m}$ thick) are associated with thick transition zone deposits. These deposits accumulated in pools, especially parts of pools opposite the downstream end of point bars. Fine-grained deposits and organic remains accumulate in pools slowly under relatively quiet water conditions during average and low-flow conditions. The fines and organics are rapidly buried during higher flow conditions as sediment-laden runoff enters the pool and drops its sediment load (including more organic remains) in response to decreases in velocity, turbulence, and gradient in the pool area. This is especially prevalent in the flow separation zone on the downstream end of point bars. Thick transition zone deposits have been recorded in northeastern Iowa fossil localities immediately upstream of fossil beaver dams (Baker et al., 1996). Though no fossil beaver dams deposits were encountered in Money or Pine Creek, it is likely that some of the thicker fossil deposits may be associated with the pool area behind beaver dams. Gradual channel migration across the floodplain, and meander abandonment by chute and neck cutoffs remove fossil localities from the active channel area, and once isolated the localities are further buried by overbank deposits during floods.

The sedimentology of the Camp Creek Member differs slightly from that of the prehistoric alluvium in the basin. Most of the Camp Creek Member in the Upper Midwest accumulated following extreme agricultural disturbance and erosion of uplands and valley wall slopes in the late 1800's and up to about 1930 (Knox, 1987; Beach, 1994; Baker et al., 1996; Bettis and Autin, 1997). Camp Creek Member alluvium mantles all valley surfaces except for T3, increasing in average thickness from $0.1-0.54 \mathrm{~m}$ where it buries the Gunder Member beneath $\mathrm{T} 2$, to $1.0 \mathrm{~m}$ where it buries 
the Roberts Creek Member beneath T1. Overlapping of Camp Creek Member alluvium onto older Holocene valley surfaces has reduced the local relief on the valley floors and obscured scarps that formerly marked contacts between terrace levels. In overbank settings Camp Creek Member alluvium accumulated during floods and does not contain macrobotanical remains. Macrobotanical remains from the Camp Creek Member were discovered at only one site, an abandoned channel, during this study. They have been discovered elsewhere only in abandoned-channel environments that were short lived and characterized by very rapid alluviation (Baker et al., 1996).

Gunder and Roberts Creek Member deposits both encompass alluvium associated with many channel positions over several thousand years. Through time channel activity has continuously removed older alluvium and associated biotic remains. The remaining alluvial fill of the valley is therefore a complex mosaic of alluvium of various ages. Apparent gaps in the depositional record in this study probably represent sampling and/or preservation bias in a small area rather than regional patterns. The stratigraphic framework of the DeForest Formation permits field recognition of three broad age groups of alluvium in the valley; that deposited between about 11500 and 5000 yr B.P. (Gunder Member), from 4500 to about 150 yr B.P. (Roberts Creek Member), and historic alluvium (Camp Creek Member). Differences in the morphology of soils developed into the Gunder Member and textural variations of the alluvium are used to distinguish early and late Gunder Member localities (Table 2). Gunder Member alluvium with basal ages ranging from about $11500-8000$ yr B.P. (early Gunder) is silt loam to light loam texture and has surface soils with Bt horizons developed into it. Soils developed in Gunder Member alluvium dating from ca. 6000-5000 yr B.P. lack Bt horizons and the alluvium is loam texture. Roberts Creek Member alluvium is significantly darker colored and contains more organic matter than the Gunder Member. Soils developed in the upper part of the Roberts Creek Member have A-Bw profiles with darker colored $\mathrm{Bw}$ horizons than soils formed in late Gunder Member alluvium. These lithologic and pedologic distinctions allow us to estimate the age of fossil localities in the field and sample the valleys' alluvium such that localities spanning the Holocene are represented.

Post-depositional alterations have differentially affected the Gunder and Roberts Creek members and associated biotic remains. Knox (1983) discussed the Holocene climatic history of the Upper Midwest as it relates to the behavior of the fluvial system and Bettis (1992) discussed the role of long-term water table relationships on the fossil record in Holocene alluvium. As a result of late middle Holocene (ca. 5500 yr B.P.), reductions in long-term precipitation, and concomitant lowering of the water table, Gunder Member deposits have been oxidized to a greater degree than Roberts Creek Member deposits (Bettis et al., 1992; Baker et al, 1992; 1996). Pollen and plant macrofossils are absent from the oxidized portion of the Gunder Member because of post-depositional degradation, are poorly preserved in the mottled and reduced zone that marks the zone of longterm water table fluctuation, and are well preserved only in the lower unoxidized portion of the unit that has remained saturated since deposition (Bettis et al., 1992; Baker et al., 1996). Organic remains are preserved through a greater thickness of the Roberts Creek Member because the water table has remained high since the unit was deposited, the lower half to third of the unit has remained saturated, and organic matter degradation has therefor been minimal. In both Money and Pine creeks a prominent zone of iron staining in Gunder Member alluvium separates overlying oxidized alluvium from underlying mottled and sometimes reduced alluvium (Fig. 2). The iron-stained zone marks the average position of the water table subsequent to accumulation of the late Gunder Member, and probably marks the late Holocene water table level. The iron accumulation zone is not as evident in Roberts Creek Member exposures, but where it can be traced from adjacent Gunder Member exposures, such as that shown in Fig. 2, it generally marks the upper limit of the zone of pollen and plant macrofossil preservation. 


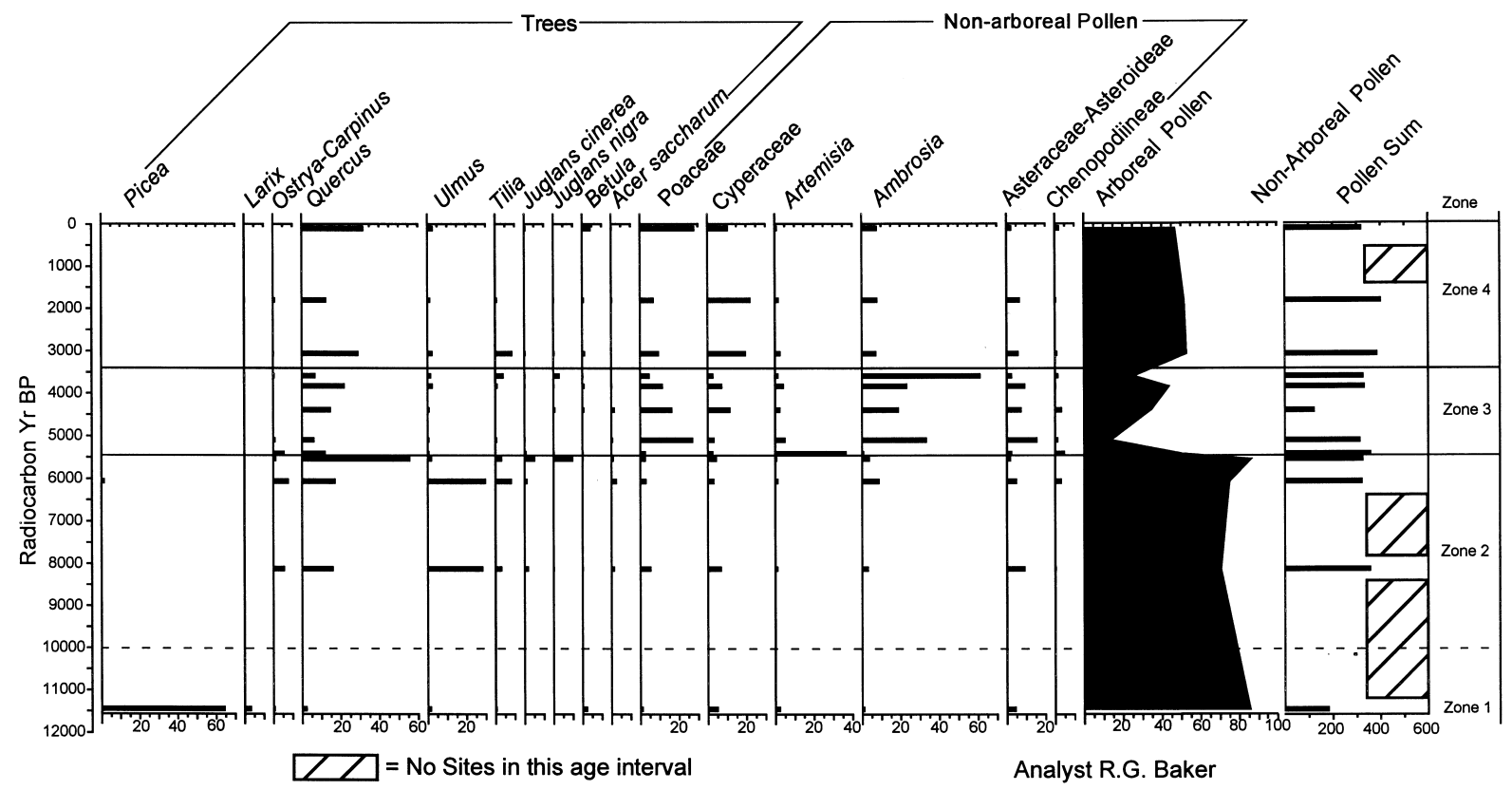

Fig. 3. Pollen diagram from Money and Pine Creeks. Sites are not in stratigraphic position, but have been arranged by individual radiocarbon dates from each cutbank section.

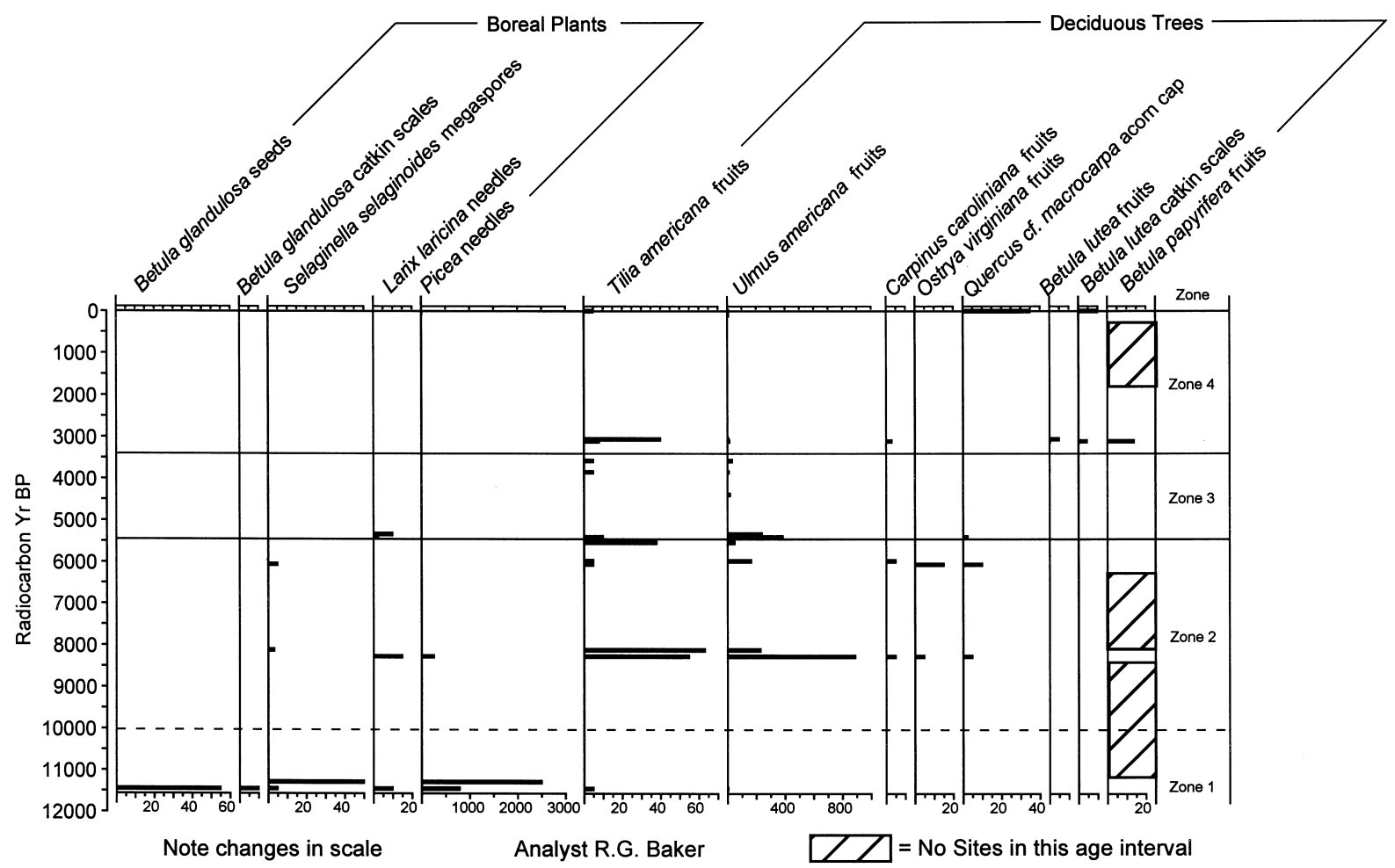

Fig. 4. Plant macrofossils of boreal plants and deciduous trees from Money and Pine Creeks. 


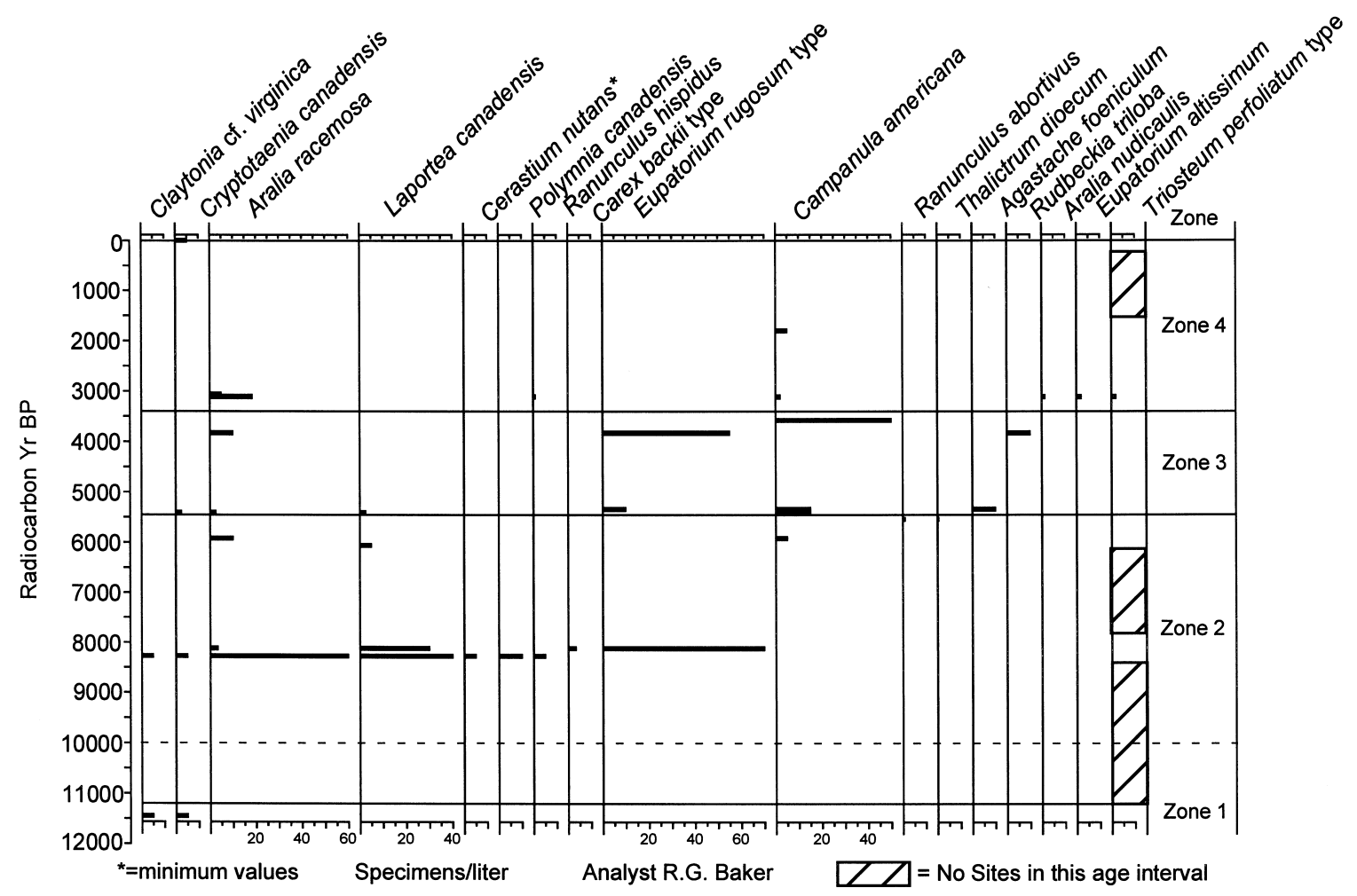

Fig. 5. Fossil fruits or seeds of forest herbs from Money and Pine Creeks.

\subsection{Vegetation history}

Although the coverage of radiocarbon-dated sites is sparse between 11450 and $6000 \mathrm{yr}$ B.P. (early Holocene), and between 1850 yr B.P. (late Holocene) and post-settlement time, coverage is sufficient to answer key questions about regional Holocene vegetational patterns. The early Holocene was a time of substantial change from forest to prairie at Kirchner Marsh (Fig. 1) and at other sites north and west. In contrast, at Roberts Creek and sites south and east, this interval was dominated by deciduous forest, with relatively minor changes within forest types. The last ca. 2000 yr were also fairly stable throughout the Midwest. The dated sites are sufficient to determine whether southeastern Minnesota followed the pattern of Kirchner Marsh and sites north and west, or that of Roberts Creek and sites south and east (Fig. 1).

\subsection{Pollen}

The pollen diagram for Money and Pine Creeks is divided into four zones by visual inspection. Zone 1 (11450-10000 yr B.P.), represented by only one site, is dominated by Picea (spruce) and Larix (larch) pollen (Fig. 3). A second site (not shown) was also dominated by these taxa, but extensive rootlet contamination prevented us from obtaining a radiocarbon age. The upper zone boundary marking the end of spruce domination is arbitrarily chosen because of the lack of sites showing the transition; approximately represents the beginning of the next regional pollen zone.

Zone 2 (10 000-5400 yr B.P.) at Money Creek is dominated by Quercus (oak) and Ulmus (elm) with relatively high values (for these taxa) of Acer saccharum, Juglans cinerea, Juglans nigra, (black walnut) and Tilia americana (Fig. 3). How- 


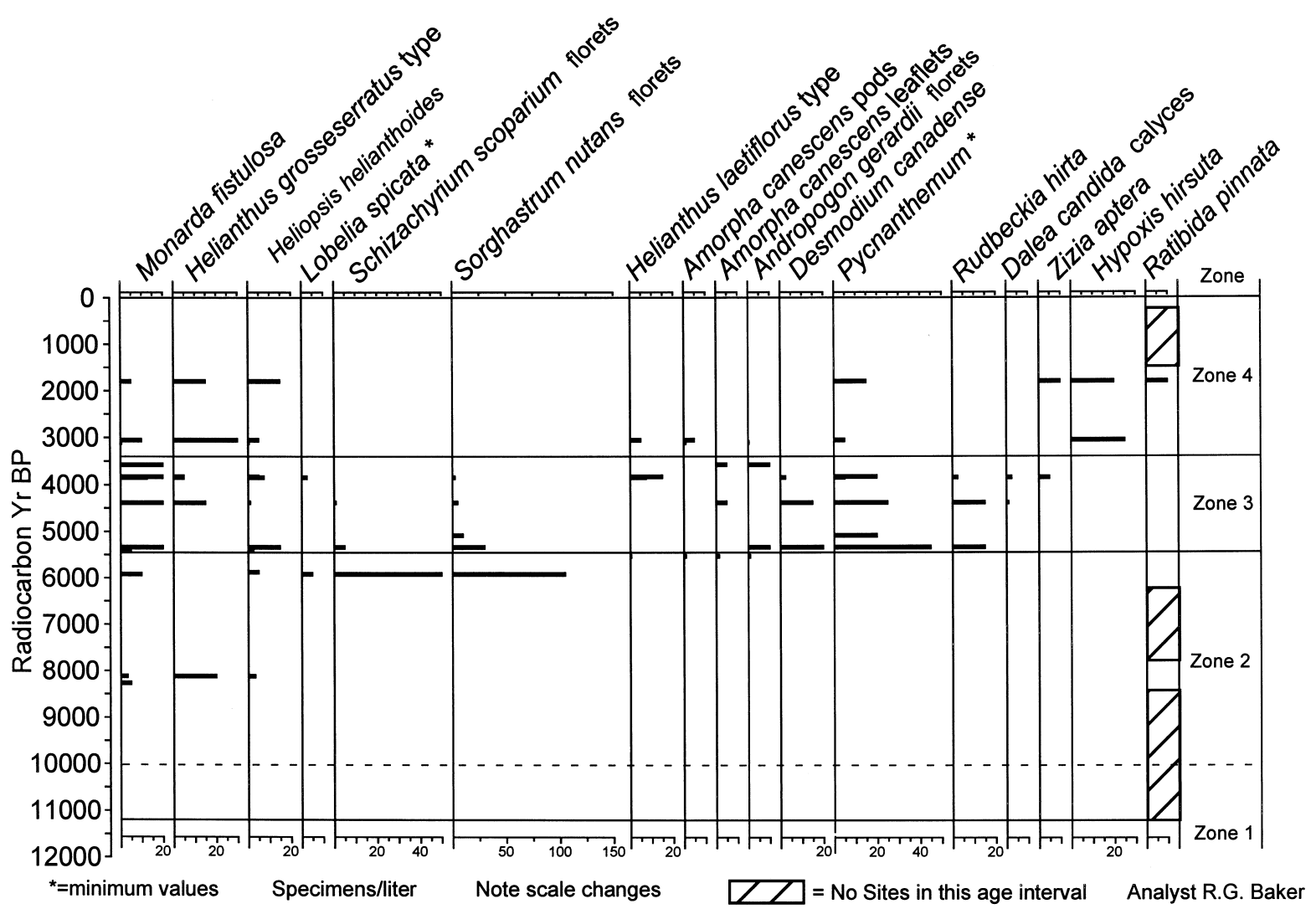

Fig. 6. Macrofossils of prairie plants from Money and Pine Creeks. All are fruits or seeds unless otherwise indicated.

ever, no fossiliferous sites were found with ages between 11290 and 8270 yr B.P. (Fig. 3), and this interval is so labeled.

The boundary between Zones 2 and 3 at ca. $5400 \mathrm{yr}$ B.P. is sharply defined by precipitous drops in the pollen of deciduous trees and in total arboreal pollen along with the rise in non-arboreal pollen, including Artemisia (wormwood) Ambrosia (ragweed), Poaceae (grass), and Asteraceae (composites) (subfamily Asteroideae) (Fig. 3). Zone 3 (5500-3400 yr B.P.) is characterized by maxima of these prairie elements. Arboreal taxa, mainly Quercus, recover somewhat in Zone 4, where arboreal and non-arboreal pollen percentages are about equal.

\subsection{Plant macrofossils}

Plant macrofossils are abundant in these sedi- ments, and they reveal a detailed picture of the Holocene environments in the area. The most abundant single taxon is Picea, whose needles reach ca. 2500/1 in Zone 1. The most abundant and diverse group are the wetland taxa, a pattern that seems predominant in midwestern stream cutbank sites. These taxa dominate on the nearstream floodplain environment throughout the Holocene. However, sufficient numbers of upland taxa are present to reconstruct some upland habitats.

Zone 1 is strongly dominated by macrofossils of boreal and subarctic plants including Betula glandulosa (dwarf birch), Selaginella selaginoides (spikemoss), Picea mariana (black spruce; cones were found), and Larix laricina (Fig. 4). Tilia, a deciduous forest element, occurs in this zone, along with such forest floor taxa as Claytonia cf. virginica (spring beauty), and Cryptotaenia cana- 


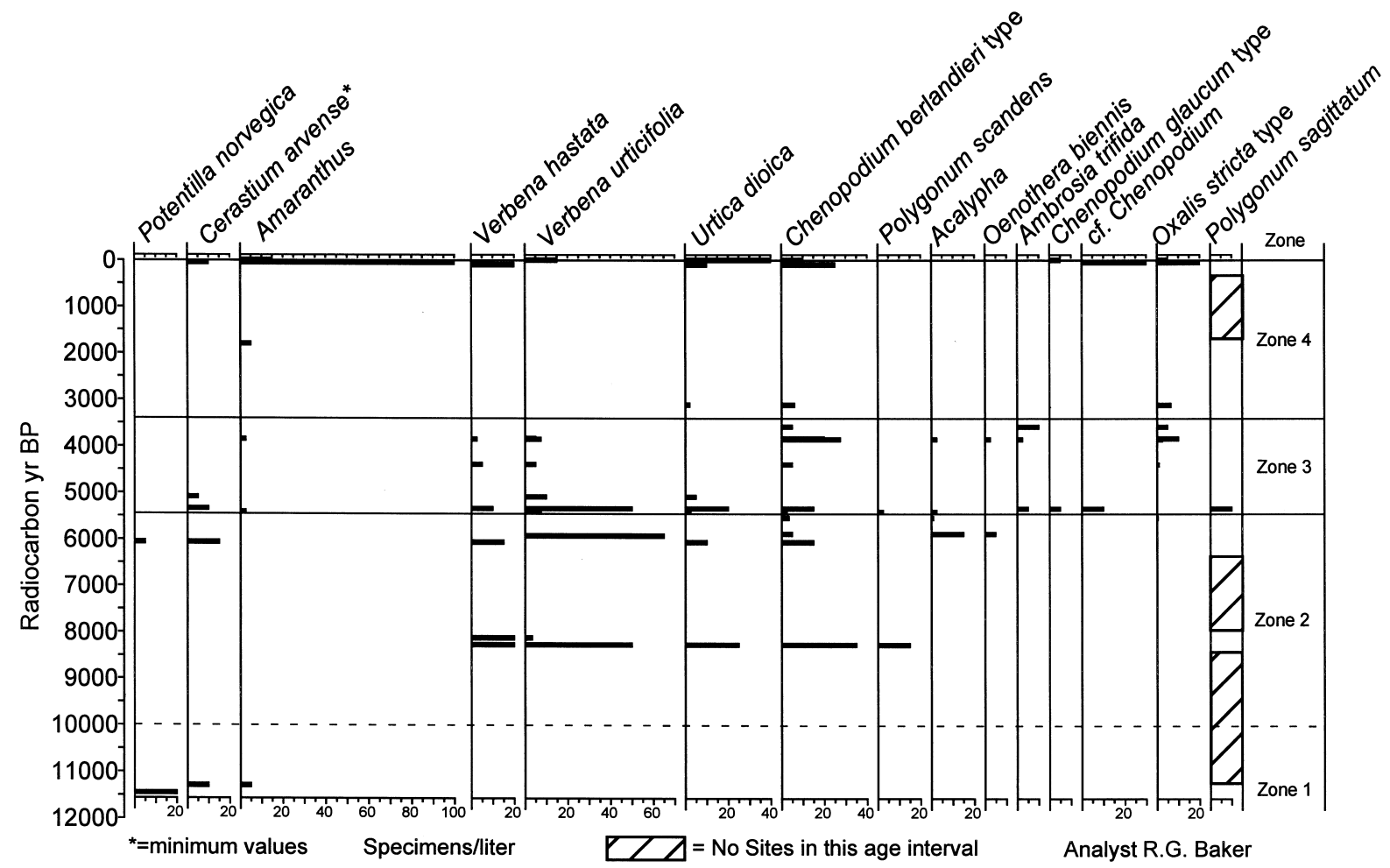

Fig. 7. Fossil fruits or seeds of Holocene weeds from Money and Pine Creeks.

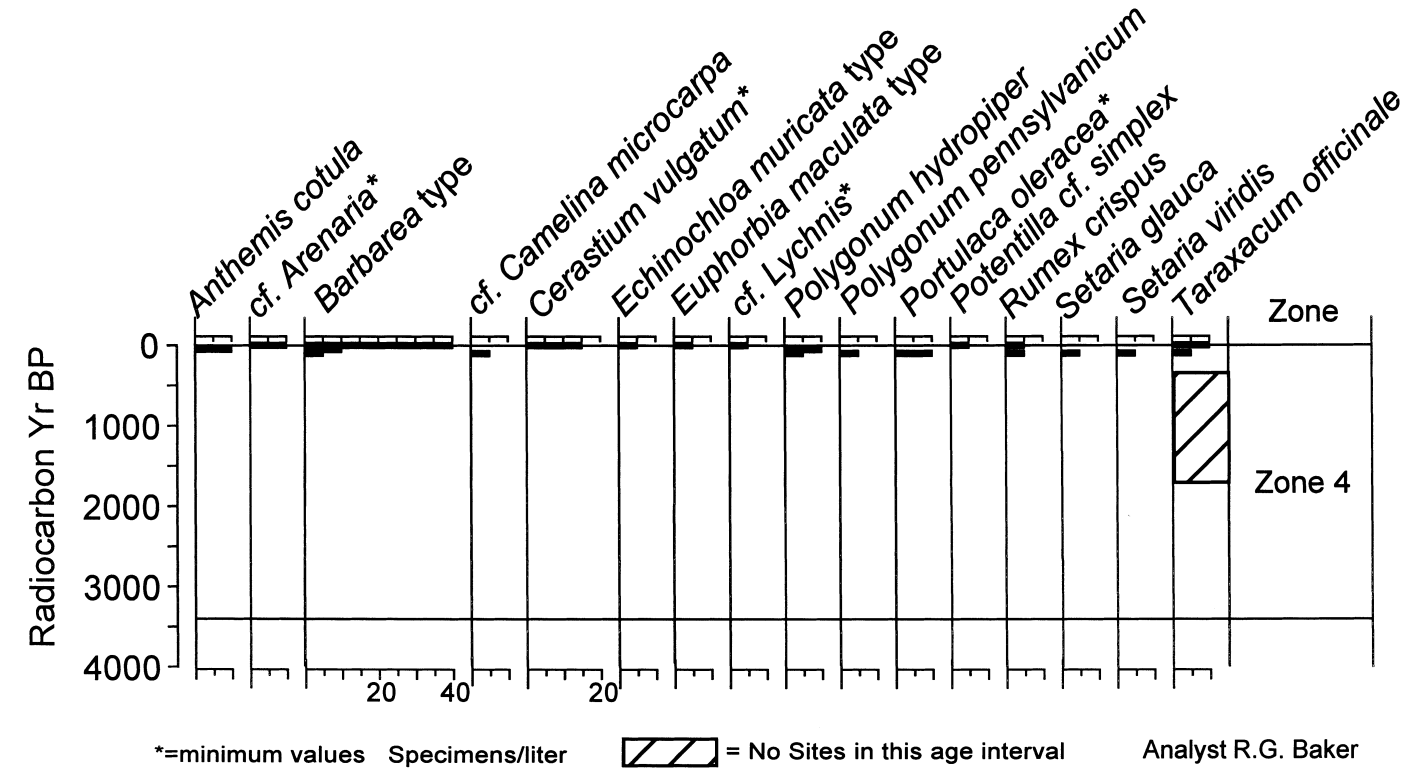

Fig. 8. Fruits or seeds of weeds, mainly introduced taxa, present only in post-settlement deposits from Money and Pine Creeks. 


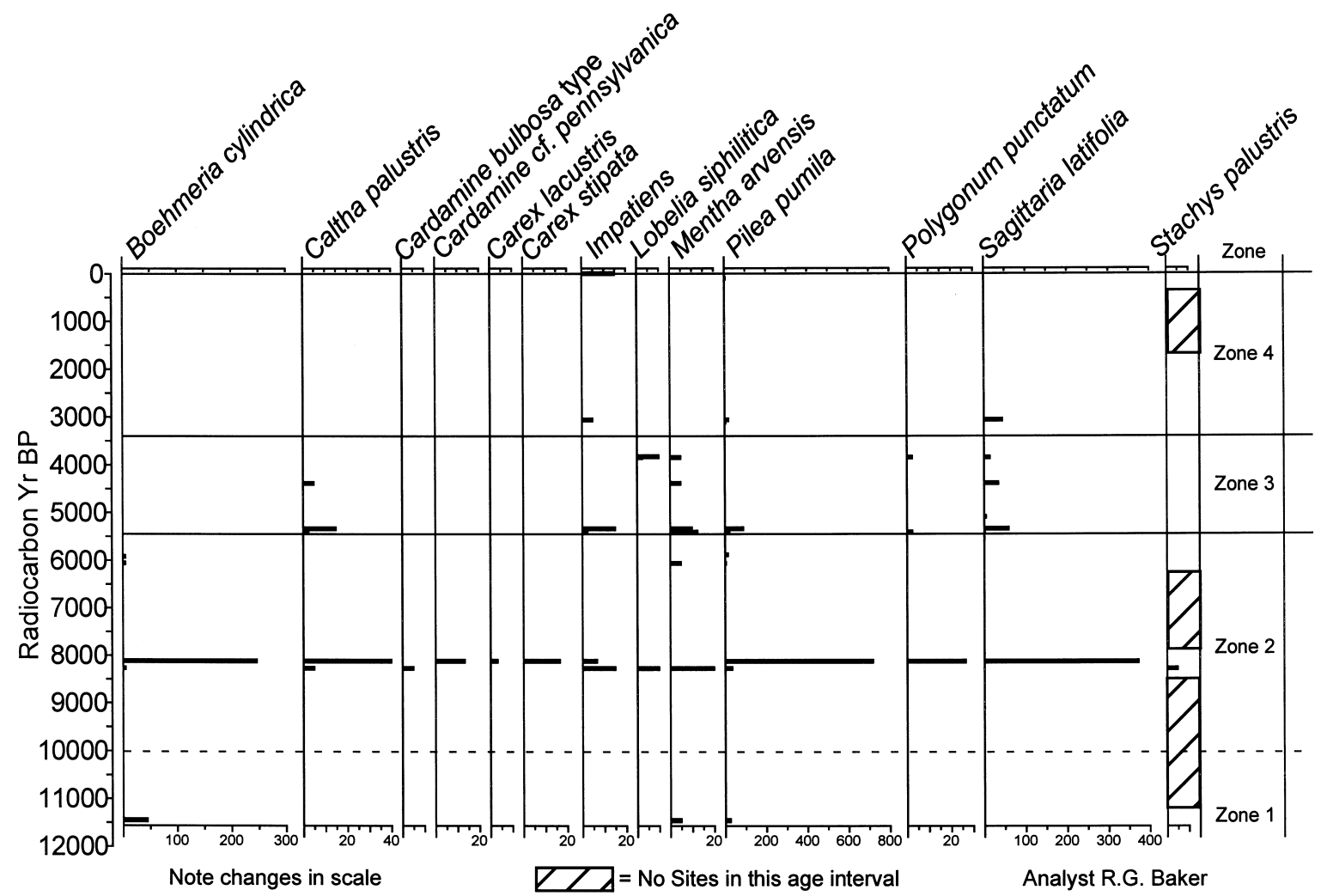

Fig. 9. Fruits or seeds of wetland taxa with maximum abundance in the early Holocene from Money and Pine Creeks.

densis (honewort) (Figs. 4 and 5). Several weedy, wetland and aquatic taxa are also represented, but the diversity of this zone is low.

Zone 2 is characterized by deciduous forest taxa. Quercus $\mathrm{cf}$. macrocarpa, Tilia americana, Ulmus americana, Carpinus caroliniana, and Ostrya virginiana are all well-represented in this zone (Fig. 4). In addition, a few tattered specimens of Picea and Larix needles and Selaginella selaginoides megaspores are present; these taxa are commonly found in mid-Holocene stream and even lake deposits in the Midwest, and they are almost certainly redeposited. Forest herbs, especially Aralia racemosa, (spikenard), Laportea canadensis (wood nettle), and Eupatorium rugosum type (white snakeroot), are abundant in the early Holocene (Fig. 5), along with the forest-edge plants Crataegus succulenta type (hawthorn), and Rubus (raspberry, blackberry). Monarda fistulosa (wild bergamot), a somewhat weedy prairie spe- cies, appears in the early Holocene samples, along with Heliopsis helianthoides (oxeye, which can grow in open woodlands) and Helianthus grosseserratus type (sawtooth sunflower, but type includes $H$. maximiliani and possibly others that may or may not be prairie species) (Fig. 6). Two of the dominant prairie grasses, Schizachyrium scoparium (Andropogon scoparius, little blue stem) and Sorghastrum nutans (Indian grass) appear only after $6000 \mathrm{yr}$ B.P. at the top of Zone 2 . Several weedy species are abundant in Zone 2 as well (Fig. 7), although many reach their peaks in post-settlement horizons (Fig. 8). Verbena hastata (common vervain), Verbena urticifolia (white vervain), Urtica dioica (nettle), and Chenopodium berlandieri type (goosefoot) are abundant ruderal taxa in Zone 2 (Fig. 7). A suite of wetland plants including Boehmeria cylindrica (false nettle), Caltha palustris (marsh-marigold), Pilea pumila (clearweed), and Sagittaria latifolia (arrowhead), 


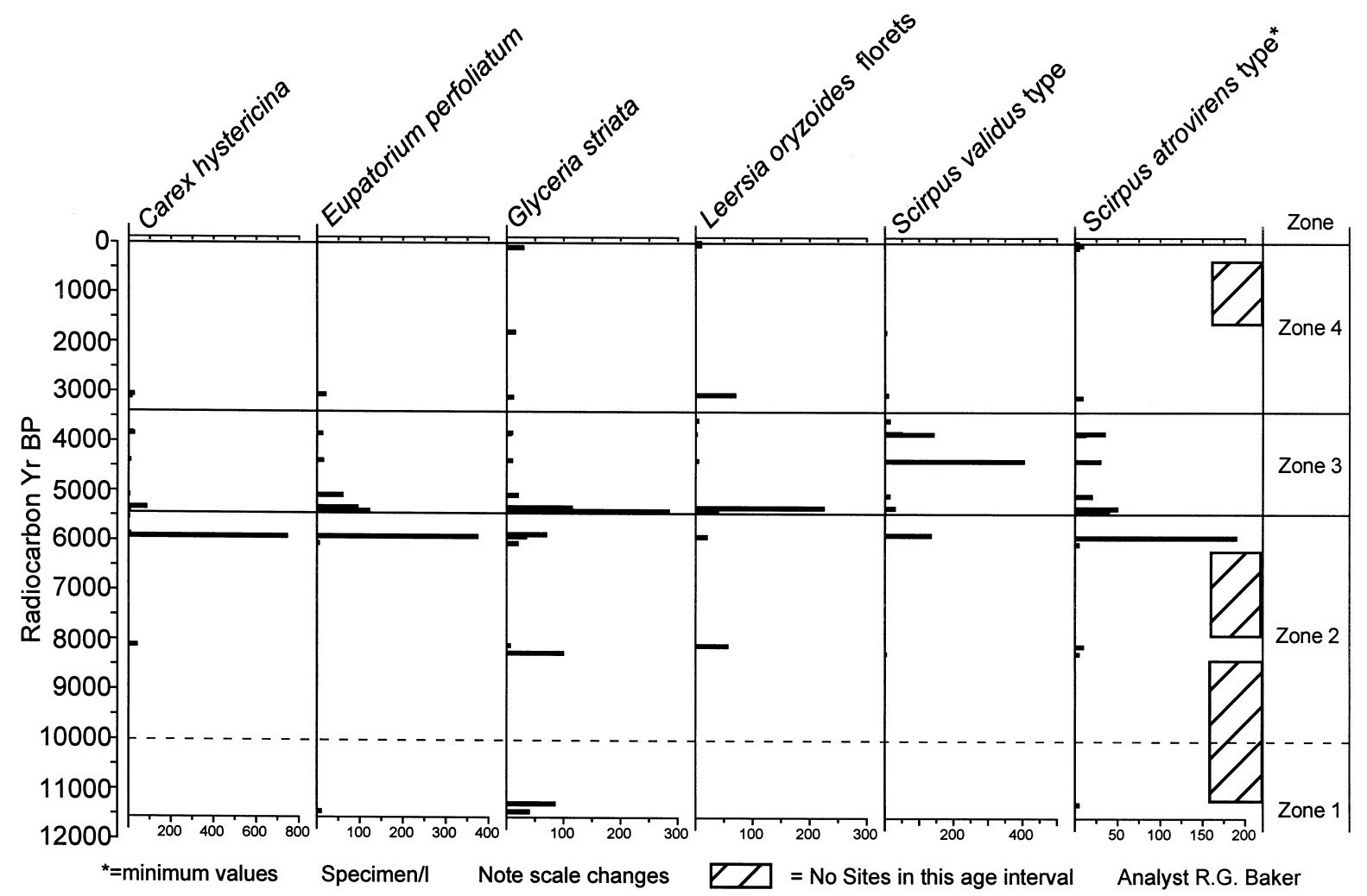

Fig. 10. Fruits or seeds, unless otherwise indicated, of wetland taxa with maximum abundance in the middle Holocene from Money and Pine Creeks.

characterizes the early Holocene and becomes less important or disappears in the middle and late Holocene (Fig. 9). Aquatic plants are also abundant in this zone.

Prairie species, including Monarda fistulosa, Sorghastrum nutans, Amorpha canescens (lead plant), Andropogon gerardii (big bluestem), Desmodium canadense (tick trefoil), Pycnanthemum (mountain mint), and Rudbeckia hirta (blackeyed susan), are concentrated in Zone 3 (Fig. 6). Macrofossils of deciduous trees and most forest herbs decline or disappear in this zone (Figs. 4 and 5). Several weedy taxa continue to be present, and others are limited or nearly limited to Zone 3 (Fig. 7). Wetland and wet prairie species including Lycopus americanus (water-horehound), Glyceria striata (slender manna grass), Epilobium coloratum (willow herb), Helenium autumnale (sneezeweed), Scirpus validus type (soft-stem bulrush),
Scirpus atrovirens (bulrush) and others are prominent in this interval (Figs. 10 and 11). Aquatic plants are common at the very beginning of this zone, but are rare thereafter.

Zone 4 is sparsely represented in the record, with samples only at 3110, 3060, and $1800 \mathrm{yr}$ B.P., along with two modern and one pre-modern but post-settlement sample. Nevertheless, trees clearly return to the record about $3000 \mathrm{yr}$ B.P., including Tilia, Ulmus americana and Carpinus caroliniana, and Betula lutea (yellow birch) and Betula papyrifera (paper birch) make their first appearance (Fig. 4). The latter two are generally found in the conifer-hardwood forest in the northern Midwest, and they have been advancing southward during the late Holocene elsewhere in the Midwest (Webb et al., 1983). Forest herbs are also present mainly at the base of this zone, with first and only occurrences of Aralia 


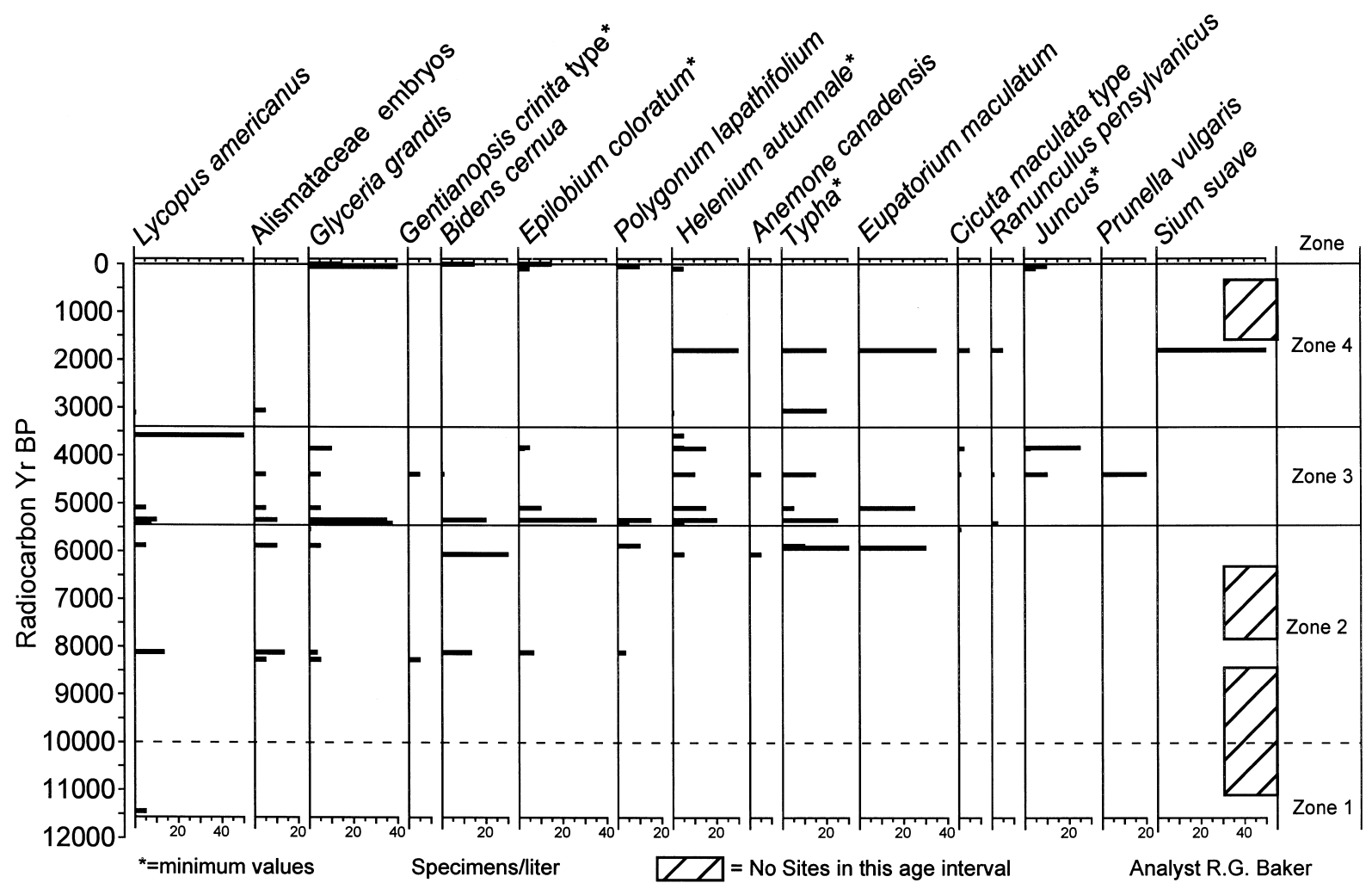

Fig. 11. Fruits or seeds, unless otherwise indicated, of other wetland taxa from Money and Pine Creeks.

nudicaulis (wild sarsaparilla), Eupatorium altissimum (tall eupatorium), and Triosteum perfoliatum/auranticum (horse-gentian), and shrubs are also mostly limited to the base of this zone (Fig. 5). Prairie plants continue to be well represented, and Hypoxis hirsuta (yellow stargrass) and Ratibida pinnata (gray-headed cone-flower) first occur in Zone 4 (Fig. 6). Weeds are sparse within the Zone, but they are the most abundant and diverse group in post-settlement and modern samples at the top of the Zone (Figs. 7 and 8). Wetland plants continue to be abundant in this interval, and Helenium autumnale, Typha, (cattail), Eupatorium maculatum (Joe-pye-weed), and Sium suave (water parsnip) reach high values at 1800 yr B.P. (Fig. 11). Aquatic plants are rare in Zone 4 and absent in modern and post-settlement sediments. Their absence is surprising, because a lush but almost wholly non-native aquatic flora including Potamogeton crispus (pondweed) and Veronica anagallis-aquatica (water speedwell), grows in parts of the modern Money Creek.

\subsection{Speleothems}

The paleoclimatic significance of Cold Water Cave stalagmite 1S is discussed in detail in Dorale et al. (1992) and Denniston et al. (1999a). In general, a cool and/or moist period from 7770 to 5900 cal. yr B.P. is characterized by low speleothem $\delta^{13} \mathrm{C}$ and $\delta^{18} \mathrm{O}$ values. $\delta^{13} \mathrm{C}$ values increase steadily beginning at 5900 cal. yr B.P. whereas $\delta^{18} \mathrm{O}$ begins increasing at $5700 \mathrm{cal}$. yr B.P. These shifts were interpreted by Dorale et al. (1992) to reflect rising middle Holocene temperatures and the replacement of deciduous forest by prairie. $\delta^{13} \mathrm{C}$ and $\delta^{18} \mathrm{O}$ values begin decreasing ca. 3300 cal. yr B.P. as trees reinvaded the prairie as oak-dominated savanna began to appear (see Fig. 12 and Table 1 for conversion of ${ }^{14} \mathrm{C}$ to calendar yr). By 2000 cal. yr B.P., soil organic matter 


\section{Speleothem Isotopes from Sites on Opposite Sides of the Ecotone}

Spring Valley Southeastern Minnesota

$\delta^{13} \mathrm{C}_{(\mathrm{PDB})}$

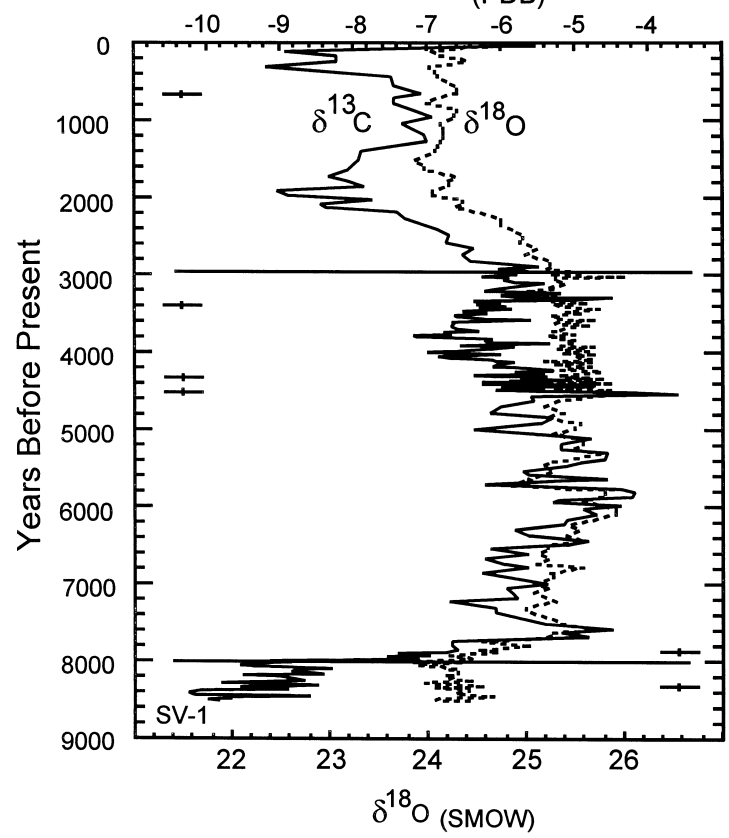

Cold Water Cave Northeastern lowa $\delta^{13} \mathrm{C}(\mathrm{PDB})$

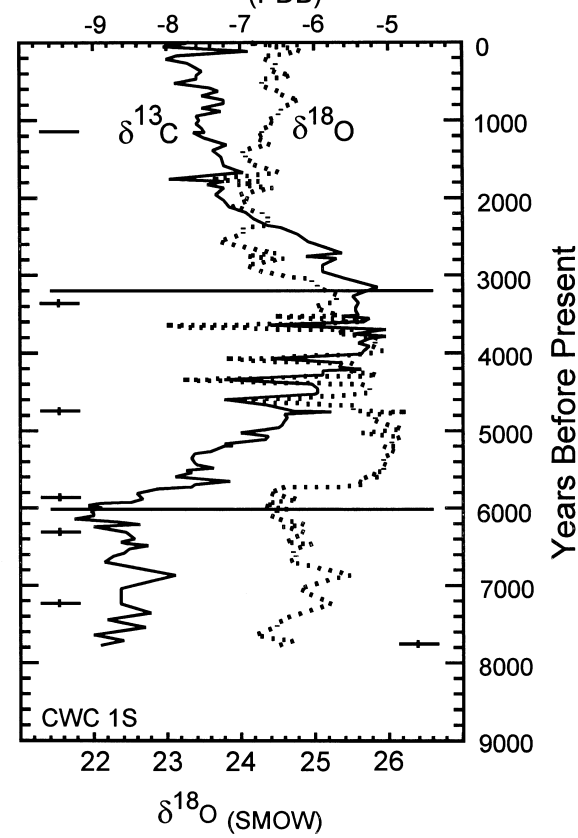

Tree and Herb Pollen from Sites on Opposite Sides of the Ecotone

${ }^{14} \mathrm{C}$ yr B.P. Kirchner Marsh, Minnesota $\quad$ Cal. yr B.P. ${ }^{14} \mathrm{C}$ yr B.P. $\quad$ Money Creek ${ }^{14} \mathrm{C}$ yr B.P. $\quad$ Roberts Creek, lowa
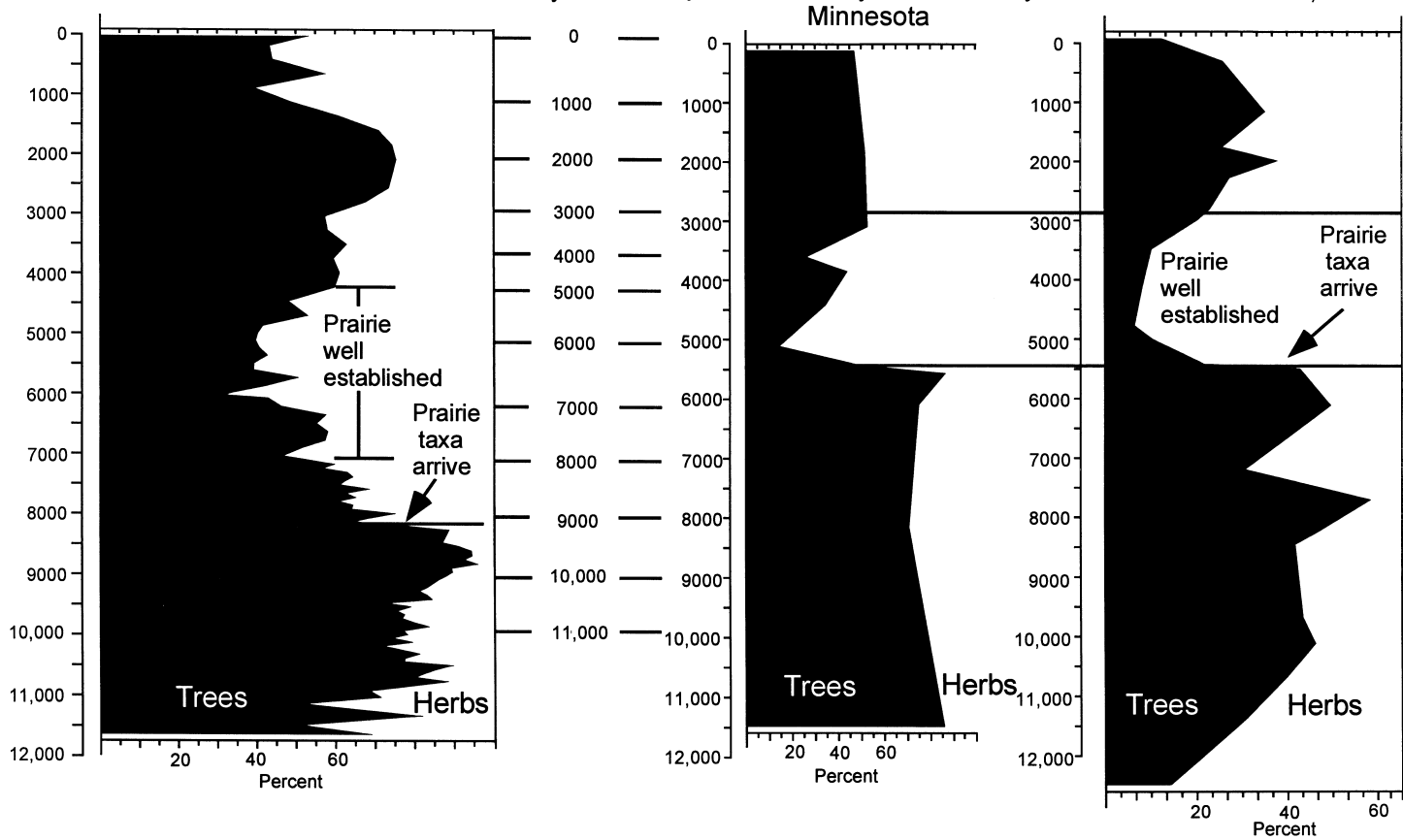
Fig. 12. Carbon and oxygen isotopes from stalagmites from Cold Water Cave and Spring Valley Cave, compared with the treeherb percentages at Kirchner, Money Creek, and Marsh Roberts Creek. Intervals on isotopic curves dated by U-Th series analysis are shown with error bars. Calibrated radiocarbon ages are shown between the Kirchner Marsh and Money Creek pollen curves to aid in comparison with the timing of the U-Th ages of the speleothems.

was once again dominated by low $\delta^{13} \mathrm{C}$ values, indicating that the savanna was well established.

Spring Valley stalagmite SV-1 records nearly identical speleothem carbon and oxygen isotopic compositions throughout the same interval. The primary difference from Cold Water Cave is the timing of the onset of higher $\delta^{13} \mathrm{C}$ values. Three stalagmites from this cave (Denniston et al., 1999a) exhibit a synchronous increase in $\delta^{13} \mathrm{C}$ values beginning about $5900 \mathrm{cal}$. yr cal. B.P. These changes reflect the increased contribution of $\mathrm{C}_{4}$ prairie grasses to the soil organic material at Spring Valley, the shift toward elevated carbon and oxygen isotopic compositions and increased $\mathrm{C}_{4}$ contributions occur at about $8000 \mathrm{cal}$. yr B.P., $2000 \mathrm{yr}$ earlier than at Cold Water Cave. At approximately $3300 \mathrm{cal}$. yr at Cold Water Cave and 3000 cal. yr B.P. at Spring Valley, $\delta^{13} \mathrm{C}$ values begin to decline, indicating partial replacement of $\mathrm{C}_{4}$ grasses by $\mathrm{C}_{3}$ plants.

\section{Discussion}

\subsection{Late-glacial and early Holocene vegetation}

The late-glacial environment in southeastern Minnesota, represented in Zone 1 at Money Creek, was dominated by Picea and Larix growing in a boreal wetland. Sediment at Site 2 contained numerous needles of these taxa, but also cones of Picea mariana, and macrofossils of Betula glandulosa and Selaginella selaginoides. These taxa indicate cold boreal to subarctic conditions in a fen or bog $1150 \mathrm{yr}$ B.P., an interpretation in agreement with those at many other midwestern sites. This interval is not represented in the speleothem records.

The boundary between Zones 1 and 2 is unclear because of the lack of samples between 11290 and 8270 yr B.P., but it undoubtedly falls within that interval. Pollen of Picea and Larix declined and were replaced by a succession of mainly deciduous trees about 10200 yr B.P. at Kirchner Marsh, about 10000 yr B.P. at Clear Lake, and between 10000 and 9000 yr B.P. at Roberts Creek. These dates suggest that the zone boundary is likely ca. 10000 yr B.P.

In Zone 2 deciduous tree pollen and plant macrofossils are abundant until after $5500 \mathrm{yr}$ B.P., and pollen of prairie taxa is scarce. The presence of several taxa of deciduous trees in the macrofossil record indicates that Zone 2 clearly represents deciduous forest that was present from at least 8270 yr B.P. until about 6000 yr B.P. Some of the weedier, more aggressive prairie taxa $(\mathrm{Mo}-$ narda fistulosa (wild bergamot), Helianthus, Heliopsis helianthoides) appeared as early as $8270 \mathrm{yr}$ B.P. Weeds in this Zone include Verbena hastata, V. urticifolia, Urtica dioica, Polygonum scandens (false buckwheat), and Acalypha (three-seeded mercury). These prairie taxa and weeds all can grow in open woods, along woodland margins, or in floodplain openings. The high arboreal pollen and presence of trees in the macrofossil record indicates that forests were still widespread until shortly after $6000 \mathrm{yr}$ B.P.

The transition between Zones 2 and 3 between 6000 and $5500 \mathrm{yr}$ B.P. marks the regional decline of the forest. The drop off of Ulmus pollen percentages occurred about 6000 yr B.P., (just when Quercus pollen was at its peak) even though $\mathrm{Ul}$ mus bud scales remained abundant until $5500 \mathrm{yr}$ B.P. This pattern may indicate that as climate became drier at 6000 , elm was no longer present in the upland forest (hence its decline on the pollen diagram), but it survived and produced bud scales along the floodplain. The increase in oak may be explained by expansion of Quercus macrocarpa, the most drought-tolerant oak, in upland forests following the decrease in elm. Some prairie plant macrofossils became prominent at $6000 \mathrm{yr}$ B.P., including two of the dominant $\mathrm{C}_{4}$ prairie grasses (Schizachyrium and Sorghastrum). These 
species were apparently able to become established locally on dry sites, but were not sufficiently widespread to be prominent on the pollen diagram. After 5500, the deciduous forest died back over much of the area.

\subsection{Late Holocene vegetation}

Zone 3 has the best coverage of sites, and it clearly shows the magnitude of changes that occurred after 5500 yr B.P. Although the diversity and abundance of prairie species is not as great as occurs further west (Baker, 2000), they nonetheless indicate a diverse prairie environment (similar to modern prairie remnants) in the late-middle Holocene. The large drop in tree pollen and the increases in the pollen of 'prairie' generalists, $A r$ temisia (at one site), Ambrosia, and Poaceae at about 5500 yr B.P. (Fig. 3) indicate that prairie replaced forest in that interval at a regional scale. The dominance of macrofossils of prairie species, the near absence of macrofossils of trees and forest herbs in Zone 3 (Fig. 4-6), and the $\delta^{13} \mathrm{C}$ values in speleothems from the two caves support this inference. This trend is remarkably similar in timing and magnitude to the sharp decline in arboreal pollen and associated changes in plant macrofossils at Roberts Creek (Fig. 12).

The sparse coverage of the last 3500 yr B.P. prevents a detailed interpretation, but the increase in arboreal pollen is a regional event between 3500 and 3000 yr B.P. Further north in central Minnesota, Grimm (1984) has demonstrated that fire played an important role in the changing positions of the prairie-forest border during the late Holocene; fire was probably important in southeastern Minnesota as well, but our data neither confirm nor refute this hypothesis. The enormous increases in macrofossils of weeds in the historical sediments (Figs. 7 and 8), including a number of alien species, demonstrates that the effects of Euro-American settlement on the landscape were extremely important, as they were at Roberts Creek (Baker et al., 1993).

\subsection{Speleothems and alluvium}

The narrow mid-Holocene ecotone between prairie and forest first suggested in Iowa by Baker et al. $(1990,1992)$ is supported by these fossil and speleothem data and extended into southeastern Minnesota. Sharp rises in carbon isotopic values at Spring Valley 8000 calendar yr B.P. indicate prairie environments. This chronology (when radiocarbon $\mathrm{yr}$ are corrected to calendar years) is comparable in timing to the changes from forest to prairie at Kirchner Marsh (Fig. 12) and in Clear Lake (Baker et al., 1992), except that the date of prairie expansion at these sites is $9000 \mathrm{cal}$. yr B.P., rather than 8000 cal. yr B.P. as shown in the speleothems. We are uncertain of the cause of this difference. It is possible that this sharp ecotone curved between these sites and reflects real differences in timing. Similar changes occur at Cold Water Cave at ca. 5900 calendar yr

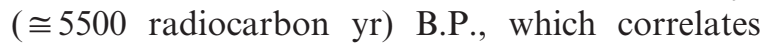
with the later change from forest to prairie at Roberts Creek (Fig. 12). Denniston et al. (1999b) argue that this early to mid-Holocene ecotone was maintained by differences in moisture along the boundary. Furthermore, stalagmite growth rates and $\delta^{18} \mathrm{O}$ changes (Denniston et al., 1999a) suggest that there was a pronounced change from summer dominated to winter dominated precipitation, rather than a decrease in annual precipitation.

The texture of overbank alluvium changed from silty to loamy between about 7000 and 6000 yr B.P. in these valleys. This change may reflect either an increasing contribution of sandy/loamy sources as the loess cover was progressively removed from uplands and slopes, or a shift to more competent flows that deposited coarser overbank alluvium. The fact that the largest point bars in these valleys formed between 6000 and $5000 \mathrm{yr}$ B.P., and that flood ramps are also more frequent in alluvium of this age, indicates that a late middle Holocene (ca. 6000-5000 yr B.P.) period of large floods occurred in these valleys. If the cool-season precipitation peak fell in the spring, as suggested by the speleothem record, then most plants would be dormant and runoff would be greater. Runoff is also considered to be greater in prairie than in forested environments. This is the time when prairie became established (Fig. 6) along the creek, and there was 
also a greater diversity in weeds, which also suggest more disturbed, open ground (Fig. 7), as would be expected with larger floods, more active channel migration, and channel widening. The trends in wetland plants also strongly reflect changes that were occurring. It is unclear from the associations why they changed or what the causes of the changes in wetland habitats were, but presumably they reflect such things as frequency and magnitude of flooding, changes in the local water table, and other factors.

\subsection{Correlation with nearby sites}

The entire Money Creek and Pine Creek sequence correlates almost exactly with the Roberts Creek sequence in northeastern Iowa, despite the fact that the Minnesota sites are in deeply dissected terrain, whereas the northeastern Iowa sites are in a relatively low relief area. Both had lateglacial spruce-larch forests followed by rich deciduous forest. Both sites had prairie establishment delayed until $5500 \mathrm{yr}$ B.P., followed by return of predominantly oak (with continuing prairie taxa). This assemblage is interpreted to represent savanna that became established between 3500 and 3000 yr B.P., and remained until settlement time. Kirchner Marsh and Clear Lake have a similar early history, but they are on the west side of the proposed mid-Holocene ecotone, where prairie began replacing deciduous forest earlier, ca. 8000 yr B.P. The return of oaks about 3500$3000 \mathrm{yr}$ B.P. is similar at all sites in the area.

\section{Conclusions:}

1. Evidence from pollen, plant macrofossils, and speleothem isotopes strongly support the existence of a sharp ecological boundary between prairie on the west and forest on the east, extending northward from eastern Iowa into southeastern Minnesota, between about 8000 and $6000 \mathrm{yr}$ B.P.

2. Combined pollen and plant macrofossils from stream cutbank exposures provide a dependable, detailed record of vegetational change that is consistent between cutbank sites in eastern Iowa and southeastern Minnesota. These deposits can provide species-level paleoenvironmental evidence in areas where no other fossil deposits exist.

3. Speleothem isotopes provide a high-resolution paleoclimatic and paleoecologic record that stands by itself, but also complements the evidence from stream alluvium and its associated plant remains.

4. Inferred changes in the seasonality of precipitation and the vegetation coincide with a change in stream behavior. In the mid-Holocene, predominantly cool-season precipitation, warm season droughts, and a change from forest to prairie (which all increase runoff) were accompanied by larger floods.

\section{Acknowledgements}

We thank Dr. Joe Mason for bringing the Pine Creek sites to our attention and Cara Day for help in sieving and picking macrofossils. Harry and Steve Walsky kindly allowed us to collect samples on their property. Thanks to Ken and Wanda Flatland at Cold Water Cave and John Ackerman at Spring Valley Cave. This work was supported by NSF Grant EAR-93-16391 and NOAA Grant NA366PO238.

\section{References}

Baker, R.G., 2000. Holocene environments reconstructed from plant macrofossils in stream deposits from southeastern Nebraska. The Holocene 10, 357-365.

Baker, R.G., Chumbley, C.A., Witinok, P.M., Kim, H.K., 1990. Holocene vegetational changes in eastern Iowa. J. Iowa Acad. Sci. 97, 167-177.

Baker, R.G., Maher, L.J., Chumbley, C.A., Van Zant, K.L., 1992. Patterns of Holocene environmental change in the Midwest. Q. Res. 37, 379-389.

Baker, R.G., Schwert, D.P., Bettis, A.E., III, 1993. The impact of EuroAmerican settlement on landscapes, vegetation and water quality in northeastern Iowa. Holocene 3, 314-323.

Baker, R.G., Bettis, E.A., III, Schwert, D.P., Horton, D.G., Chumbley, C.A., Gonzalez, L.A., Reagan, M.K., 1996. Holocene paleoenvironments of northeast Iowa. Ecol. Monogr. 66, 203-234.

Baker, R.G., Gonzalez, L.A., Raymo, M., Bettis, E.A., III, Reagan, M.K., Dorale, J.A., 1998. Comparison of multiple 
proxy records of Holocene environments in midwestern USA. Geology 26, 1131-1134.

Barnosky, C.W., Grimm, E.C., Wright, H.E., Jr., 1987. Towards a postglacial history of the northern Great Plains: A review of the paleoecologic problems. Ann. Carnegie Mus. 56, 259-273.

Beach, T., 1994. The fate of eroded soil: Sediment sinks and sediment budgets of agrarian landscapes in southern Minnesota, 1851-1988. Ann. Assoc. Am. Geogr. 84, 5-28.

Bettis, E.A. III, 1992. Soil Morphologic properties and weathering zone characteristics as age indicators in Holocene alluvium in the Upper Midwest. In: V.T. Holliday, (Ed.), Soils in Archaeology. Smithsonian Institution Press, Washington, DC, pp. 119-144.

Bettis, E.A., III, Autin, W.J., 1997. Complex response of a midcontinent North America drainage system to late Wisconsinan sedimentation. J. Sediment. Res. 67, 740-748.

Bettis, E.A. III, Baker, R.G., Green, W.R., Whelan, M.K., Benn, D.W., 1992. Late Wisconsinan and Holocene alluvial stratigraphy, paleoecology, and archaeological geology of east-central Iowa. Iowa Department of Natural Resources Guidebook Series No. 12. Iowa Department of Natural Resources, Iowa City, IA.

Boutton, T.W., 1991. Stable carbon isotope ratios of natural materials. II. Atmospheric, terrestrial, marine, and freshwater environments. In: Coleman, D.C., Fry, B. (Eds.), Carbon Isotope Techniques. Academic Press. San Diego, CA, pp. 155-171.

Bradbury, J.P., Dean, W.E., 1993. Elk Lake, Minnesota: Evidence for rapid climate change in the North-Central United States. Geological Society of America Special Paper 276, Geological Society of America, Boulder, CO.

Chen, J., Edwards, L., Wasserburg, W., 1986. ${ }^{238} \mathrm{U},{ }^{234} \mathrm{U}$, and ${ }^{232} \mathrm{Th}$ in seawater. Earth Planet. Sci. Lett. 80, 241-251.

Chumbley, C.A., Baker, R.G., Bettis, E.A., III, 1990. Midwestern Holocene paleoenvironments revealed by floodplain deposits in northeastern Iowa. Science 249, 272-274.

Cushing, E.J., 1965. Problems in the Quaternary phytogeography of the Great Lakes Region. In: Wright, H.E. Jr., Frey, D.G. (Eds.), The Quaternary of the United States. Princeton University Press, Princeton, NJ, pp. 403-416.

Denniston, R.F., Gonzalez, L.A., Asmerom, Y., Baker, R.G., Reagan, M.K., Bettis, E.A., III, 1999a. Evidence for increased cool season moisture during the middle Holocene. Geology 27, 815-818.

Denniston, R.F., Gonzalez, L.A., Baker, R.G., Asmerom, Y., Reagan, M.K., Edwards, R.L., Alexander, C.E., 1999b. Speleothem evidence for Holocene fluctuations of the prairieforest ecotone, north-central USA. The Holocene 9, 671676.

Dorale, J.A., Gonzalez, L.A., Reagan, M.K., Pickett, D.A., Murrell, M.T., Baker, R.G., 1992. A high-resolution record of Holocene climate change in speleothem calcite from Cold Water Cave, northeast Iowa. Science 258, 1626-1630.

Edwards, R.L., Beck, J.W., Burr, C.S., Donahue, D.J., Chappell, J.M.A., Bloom, A.L., Druffel, E.R.M., Taylor, F.W., 1993. A large drop in atmospheric ${ }^{14} \mathrm{C} /{ }^{12} \mathrm{C}$ and reduced melting in the Younger Dryas documented with ${ }^{230} \mathrm{Th}$ ages of corals. Science 260, 962-968.

Edwards, R.L., Chen, J.H., Wasserburg, G.J., 1987. ${ }^{238} \mathrm{U}_{-}$ ${ }^{234} \mathrm{U}-{ }^{230} \mathrm{Th}$ systematics and the precise measurement of time over the last 500000 years. Earth Planet. Sci. Lett. 81, 175-192.

Faegri, K, Kaland, P.E., Krzywinski, K., 1989. Textbook of Pollen Analysis. John Wiley and Sons, New York.

Gleason, H.A., 1922. The vegetational history of the Middle West. Assoc. Am. Geogr. Ann. 12, 39-85.

Grimm, E.C., 1984. Fire and other factors controlling the Big Woods in the mid-nineteenth century. Ecol. Monogr. 54, 291-311

Hendy, C.H., Wilson, A.T., 1968. Palaeoclimatic data from speleothems. Nature 216, 48-51.

Hobbs, H.C., 1995. Surficial geology (Plate 3). In: Lively, R.S., Balaban, N.H., (Eds.) Geologic atlas, Fillmore County, Minnesota. Minnesota Geological Survey County Atlas Series C-12, Pt. A, scale 1:100, 000. Minnesota Geological Survey, Minneapolis, MN.

Knox, J.C., 1983. Response of river systems to to Holocene climates. In: H.E. Wright Jr., (Ed.) Late-Quaternary Environments of the United States. Vol. 2: The Holocene. University of Minnesota Press, Minneapolis, MN, pp. 26-41.

Knox, J.C., 1985. Responses of floods to Holocene climatic change in the Upper Mississippi Valley. Q. Res. 23, 287-300.

Knox, J.C., 1987. Historical valley floor sedimentation in the Upper Mississippi River Valley. Ann. Assoc. Am. Geogr. 77, 224-244.

Knox, J.C., 1993. Large increases in flood magnitude in response to modest changes in climate. Nature 361, 430-432.

Knox, J.C., Attig, J.W., 1988. Geology of the Pre-Illinoian sediment in the Bridgeport Terrace, Lower Wisconsin River Valley, Wisconsin. J. Geol. 96, 505-513.

McAndrews, J.H., 1966. Postglacial history of prairie, savanna, and forest in northwestern Minnesota. Torrey Botanical Club Memoir 22, 72 pp.

Prior, J.C., 1991. Landforms of Iowa. University of Iowa Press, Iowa City, IA.

Soil Survey Staff, 1993. Soil Survey Manual, U.S. Department of Agriculture Handbook No. 18, Washington, DC.

Strickland, L.E., 1998. Taphonomy of plant remains in Prairie Creek, Nerstrand Big Woods State Park, Rice County, Minnesota: A modern analog for paleoenvironmental interpretation. M.S. Thesis, University of Iowa, Iowa City, IA.

Watts, W.A., Winter, T.C., 1966. Plant macrofossils from Kirchner Marsh, Minnesota - A paleoecological study. Geol. Soc. Am. Bull. 77, 1339-1360.

Webb, T. III, Cushing, E.J., Wright, H.E. Jr., 1983. Holocene changes in the vegetation of the midwest, In: Wright, H.E. Jr. (Ed.), Late Quaternary Environments of the United States, Vol. 2, The Holocene. University of Minnesota Press, Minneapolis, MN, pp. 143-165.

Wright, H.E. Jr., 1968. History of the Prairie Peninsula. In: Bergstrom, R.E. (Ed.), The Quaternary of Illinois. University of Illinois College of Agriculture Special Publication no. 14, Urbana, IL, pp. 78-88. 